\title{
Inverse modelling of $\mathrm{CH}_{4}$ emissions for 2010-2011 using different satellite retrieval products from GOSAT and SCIAMACHY
}

\author{
M. Alexe ${ }^{1}$, P. Bergamaschi ${ }^{1}$, A. Segers ${ }^{2}$, R. Detmers ${ }^{3}$, A. Butz ${ }^{9}$, O. Hasekamp ${ }^{3}$, S. Guerlet ${ }^{3}$, R. Parker ${ }^{4}$, H. Boesch ${ }^{4}$, \\ C. Frankenberg ${ }^{5}$, R. A. Scheepmaker ${ }^{3}$, E. Dlugokencky ${ }^{6}$, C. Sweeney ${ }^{6,7}$, S. C. Wofsy ${ }^{8}$, and E. A. Kort ${ }^{10}$ \\ ${ }^{1}$ European Commission, Joint Research Centre, Institute for Environment and Sustainability, Air and Climate Unit, Ispra, Italy \\ ${ }^{2}$ Netherlands Organisation for Applied Scientific Research (TNO), Utrecht, the Netherlands \\ ${ }^{3}$ Netherlands Institute for Space Research (SRON), Utrecht, the Netherlands \\ ${ }^{4}$ Earth Observation Science Group, Space Research Centre, University of Leicester, Leicester, UK \\ ${ }^{5}$ Jet Propulsion Laboratory, California Institute of Technology, Pasadena, California, USA \\ ${ }^{6}$ Global Monitoring Division, NOAA Earth System Research Laboratory, Boulder, Colorado, USA \\ ${ }^{7}$ CIRES, University of Colorado, Boulder, Colorado, USA \\ ${ }^{8}$ School of Engineering and Applied Science and Department of Earth and Planetary Sciences, Harvard University, \\ Cambridge, Massachusetts, USA \\ ${ }^{9}$ Karlsruhe Institute of Technology (KIT), Karlsruhe, Germany \\ ${ }^{10}$ Department of Atmospheric, Oceanic and Space Sciences, University of Michigan, Michigan, USA
}

Correspondence to: M. Alexe (mihai.alexe@jrc.ec.europa.eu)

Received: 13 March 2014 - Published in Atmos. Chem. Phys. Discuss.: 8 May 2014

Revised: 31 October 2014 - Accepted: 21 November 2014 - Published: 9 January 2015

\begin{abstract}
At the beginning of 2009 new space-borne observations of dry-air column-averaged mole fractions of atmospheric methane $\left(\mathrm{XCH}_{4}\right)$ became available from the Thermal And Near infrared Sensor for carbon Observations-Fourier Transform Spectrometer (TANSO-FTS) instrument on board the Greenhouse Gases Observing SATellite (GOSAT). Until April 2012 concurrent methane $\left(\mathrm{CH}_{4}\right)$ retrievals were provided by the SCanning Imaging Absorption spectroMeter for Atmospheric CartograpHY (SCIAMACHY) instrument on board the ENVironmental SATellite (ENVISAT). The GOSAT and SCIAMACHY $\mathrm{XCH}_{4}$ retrievals can be compared during the period of overlap. We estimate monthly average $\mathrm{CH}_{4}$ emissions between January 2010 and December 2011, using the TM5-4DVAR inverse modelling system. In addition to satellite data, high-accuracy measurements from the Cooperative Air Sampling Network of the National Oceanic and Atmospheric Administration Earth System Research Laboratory (NOAA ESRL) are used, providing strong constraints on the remote surface atmosphere. We discuss five inversion scenarios that make use of different GOSAT and SCIAMACHY $\mathrm{XCH}_{4}$ retrieval products, including two sets of GOSAT proxy retrievals processed
\end{abstract}

independently by the Netherlands Institute for Space Research (SRON)/Karlsruhe Institute of Technology (KIT), and the University of Leicester (UL), and the RemoTeC "FullPhysics" (FP) $\mathrm{XCH}_{4}$ retrievals available from SRON/KIT. The GOSAT-based inversions show significant reductions in the root mean square (rms) difference between retrieved and modelled $\mathrm{XCH}_{4}$, and require much smaller bias corrections compared to the inversion using SCIAMACHY retrievals, reflecting the higher precision and relative accuracy of the GOSAT $\mathrm{XCH}_{4}$. Despite the large differences between the GOSAT and SCIAMACHY retrievals, 2-year average emission maps show overall good agreement among all satellitebased inversions, with consistent flux adjustment patterns, particularly across equatorial Africa and North America. Over North America, the satellite inversions result in a significant redistribution of $\mathrm{CH}_{4}$ emissions from North-East to South-Central United States. This result is consistent with recent independent studies suggesting a systematic underestimation of $\mathrm{CH}_{4}$ emissions from North American fossil fuel sources in bottom-up inventories, likely related to natural gas production facilities. Furthermore, all four satellite inversions yield lower $\mathrm{CH}_{4}$ fluxes across the Congo basin 
compared to the NOAA-only scenario, but higher emissions across tropical East Africa. The GOSAT and SCIAMACHY inversions show similar performance when validated against independent shipboard and aircraft observations, and $\mathrm{XCH}_{4}$ retrievals available from the Total Carbon Column Observing Network (TCCON).

\section{Introduction}

Atmospheric methane $\left(\mathrm{CH}_{4}\right)$ is the second-most important anthropogenic greenhouse gas (GHG) - after carbon dioxide $\left(\mathrm{CO}_{2}\right)$ - in terms of net radiative forcing (RF). Emissions of $\mathrm{CH}_{4}$ have caused an $\mathrm{RF}$ of $0.97 \mathrm{~W} \mathrm{~m}^{-2}$ (Stocker et al., 2013), about twice the concentration-based estimate $\left(0.48 \mathrm{~W} \mathrm{~m}^{-2}\right)$. After a period of stabilization from 1999 to 2006 (Dlugokencky et al., 2003; Simpson et al., 2006), $\mathrm{CH}_{4}$ concentrations in the atmosphere have started to rise again (Dlugokencky et al., 2009; Rigby et al., 2008; Nisbet et al., 2014), and are currently estimated to be $160 \%$ higher than preindustrial (1750) values (WMO, 2013). Previous research has identified the main sources and sinks of atmospheric $\mathrm{CH}_{4}$; however, there remain considerable uncertainties regarding their relative importance (Kirschke et al., 2013).

Since large-scale regional or global $\mathrm{CH}_{4}$ fluxes cannot be directly measured, attempts at estimating these quantities have traditionally relied on two complementary techniques: "bottom-up" emission inventories, and inverse modelling ("top-down"). Bayesian inverse modelling (Tarantola, 2004) of $\mathrm{CH}_{4}$ emissions operates under a well-defined mathematical framework that combines a priori information on $\mathrm{CH}_{4}$ emissions, atmospheric observations, and an atmospheric chemistry and transport model (CTM), to yield a statistical best estimate of $\mathrm{CH}_{4}$ emissions and concentrations over the time period of interest. The quality of the estimates obtained through inverse modelling depends in large part on the quality of the observation data available for the spatial and temporal domains of interest, and on the quality of the CTM.

Surface measurements of $\mathrm{CH}_{4}$ concentrations are available from global networks such as the Cooperative Air Sampling Network of the National Oceanic and Atmospheric Administration Earth System Research Laboratory (NOAA ESRL) (Dlugokencky et al., 1994, 2009, 2013). However, surface observations provide only sparse global coverage, with the exception of certain regions, mainly Europe and North America, where regional monitoring stations, including tall towers and aircraft profiles, have been set up in recent years (e.g. Vermeulen et al., 2007). Surface measurements provide effective constraints on regional emissions (Bergamaschi et al., 2010; Kort et al., 2008; Miller et al., 2013); however, they are not available in many important emission regions, such as the tropics. Inversions based on global background sites have provided a good picture of global and continental $\mathrm{CH}_{4}$ emissions, their trends, and inter-annual variability (Bergam- aschi et al., 2013a; Houweling et al., 1999; Bousquet et al., 2006; Hein et al., 1997; Mikaloff Fletcher et al., 2004a, b). Smaller-scale regional patterns, however, largely remain determined by the prior emission inventories (due to lack of observations).

Since 2002, satellite retrievals of total-column $\mathrm{CH}_{4}$ mixing ratios have been available from the SCanning Imaging Absorption spectroMeter for Atmospheric CHartographY (SCIAMACHY) instrument on board the ENVironmental SATellite, ENVISAT (Frankenberg et al., 2005, 2006, 2008, 2011; Buchwitz et al., 2005; Schneising et al., 2012). The SCIAMACHY data were the first space-borne $\mathrm{XCH}_{4}$ retrievals sensitive to the atmospheric boundary layer. This new data set, along with an extension in data coverage to previously observation-poor areas, such as the tropics, led to the first global and regional inversions of $\mathrm{CH}_{4}$ fluxes (Bergamaschi et al., 2007, 2009; Frankenberg et al., 2008; Meirink et al., 2008a). Due to the relatively long operational lifetime of SCIAMACHY (almost one decade), the $\mathrm{XCH}_{4}$ retrievals from this instrument were useful for analysing the interannual $\mathrm{CH}_{4}$ variability (IAV) during this period (Bergamaschi et al., 2013a). However, the impact of the serious detector pixel degradation, which occurred at the end of 2005 , remains difficult to evaluate, despite overall consistency of the SCIAMACHY time series with surface observations (Frankenberg et al., 2011).

Since 2009, $\mathrm{XCH}_{4}$ retrievals have also become available from the Greenhouse Gases Observing SATellite (GOSAT) Thermal And Near infrared Sensor for carbon ObservationsFourier Transform Spectrometer (TANSO-FTS) instrument (Parker et al., 2011; Yoshida et al., 2011; Butz et al., 2011). Given the limited lifetime of satellite instruments (the communication link to ENVISAT was lost in April 2012, while the GOSAT mission plans extend only until 2014), inverse modelling comparison studies using different satellite retrievals are of great importance for understanding the difference between products. Such analyses are a crucial step when using satellite data to analyse IAV and trends. Within the European project Monitoring Atmospheric Composition and Climate - Interim Implementation (MACC-II) preoperational "delayed-mode" $\mathrm{CH}_{4}$ flux inversions are performed, which are updated every six months (Bergamaschi et al., 2013b). Beginning in 2012 the assimilated satellite data set changed from SCIAMACHY IMAPv5.5 to GOSAT RemoTeC v2.0 (Bergamaschi et al., 2013b). Furthermore, alternative $\mathrm{XCH}_{4}$ products from GOSAT and SCIAMACHY have been developed within the European Space Agency GHG Climate Change Initiative (ESA-GHG CCI) project (Buchwitz et al., 2013).

This study will present a detailed comparison of global $\mathrm{CH}_{4}$ flux inversions constrained by different GOSAT and SCIAMACHY retrieval products and surface measurements, covering the 2-year period between January 2010 and December 2011. The availability of multiple satellite retrieval products covering the same time interval allows for a de- 
Table 1. Satellite data used in the inversions.

\begin{tabular}{lllll}
\hline Satellite/Instrument & Algorithm & Proxy $\mathrm{CO}_{2}$ model & Data provider & Temporal data coverage \\
\hline ENVISAT/SCIAMACHY & IMAP v5.5 & CarbonTracker & SRON & Jan 2009-Mar 2012 \\
GOSAT/TANSO-FTS & OCPR v4.0 & LMDZ & Univ. of Leicester & Jun 2009-Dec 2011 \\
GOSAT/TANSO-FTS & RemoTeC Proxy v1.9/v2.0 & CarbonTracker 2013 & SRON/KIT & v1.9: Jan 2009-Oct 2011 \\
& & & SRON/KIT & v2.0: Oct 2011-Jun 2012 \\
GOSAT/TANSO-FTS & RemoTeC FP v2.1 & - & Jun 2009-Jun 2012 \\
\hline
\end{tabular}

tailed comparison of their consistency and added value in inverse modelling, which is the main objective of this paper. Three recent inverse modelling studies (Fraser et al., 2013; Monteil et al., 2013; Cressot et al., 2014) have made use of SCIAMACHY and GOSAT $\mathrm{XCH}_{4}$ to estimate global $\mathrm{CH}_{4}$ fluxes and concentrations. Our approach differs significantly from previous studies in that we examine an extended time period, use a different inversion set-up, and employ several distinct (optimized) bias correction strategies for the SCIAMACHY and GOSAT retrievals. Another novel element of this study is the comparison of two different satellite proxy retrievals: the GOSAT RemoTeC data set (Schepers et al., 2012) from SRON/KIT, and the OCPR GOSAT retrievals from the University of Leicester (UL) (Parker et al., 2011). We also assimilate the "Full-Physics" (FP) GOSAT retrievals from SRON/KIT, which do not require the use of modelled $\mathrm{CO}_{2}$ fields. Furthermore, we invert the SCIAMACHY IMAPv5.5 retrievals as used in the MACC reanalysis (Bergamaschi et al., 2013a). In addition to the GOSAT and SCIAMACHY satellite retrievals, all inversions are constrained by high-accuracy $\mathrm{CH}_{4}$ surface data from the NOAA ESRL Cooperative Air Sampling Network. We also present a detailed validation of the inversion results against independent NOAA ship and aircraft profile samples, the aircraft transects from HIPPO - the High-performance Instrumented Airborne Platform for Environmental Research (HIAPER) Pole-to-Pole observation (HIPPO) campaigns from 2010 and 2011, and $\mathrm{XCH}_{4}$ data from the Total Carbon Column Observation Network (TCCON) FTS (Wunch et al., 2010). Finally, we discuss the impact of several bias correction approaches on the estimated total emissions.

This paper is organized as follows. Section 2 summarizes the main characteristics of the satellite and surface observations used in the inversion. The inverse modelling framework is described briefly in Sect. 3. In Sect. 4, we present and discuss the $\mathrm{CH}_{4}$ emission estimates for the various inversion scenarios, and the validation of the model simulations against independent measurement data. Finally, the conclusions of the study are summarized in Sect. 5 .

\section{Observations}

Table 1 gives an overview of the satellite data used in the inversions. The following sub-sections briefly discuss the char- acteristics of each set of satellite retrievals. Further details are provided in the studies of Parker et al. (2011), Butz et al. (2011), Frankenberg et al. (2011), and Schepers et al. (2012).

\subsection{The GOSAT retrievals}

The TANSO-FTS, on board the satellite GOSAT (launched by JAXA in January 2009), provides dry-air columnaveraged $\mathrm{CH}_{4}$ mole fractions that can be used in global and regional $\mathrm{CH}_{4}$ source and sink inversions. The GOSAT $\mathrm{XCH}_{4}$ are retrieved from a short-wave infrared spectral analysis of sunlight backscattered by the Earth's surface and atmosphere.

The proxy retrieval algorithms rely on the small spectral distance between $\mathrm{CO}_{2}$ and $\mathrm{CH}_{4}$ sunlight absorption bands $\left(1.6 \mu \mathrm{m}\right.$ for $\mathrm{CO}_{2}$ and $1.65 \mu \mathrm{m}$ for $\left.\mathrm{CH}_{4}\right)$, using the $\mathrm{CO}_{2}$ column-average dry-air mole fraction $\left(\mathrm{XCO}_{2}\right)$ as proxy for the sampled air mass. This helps minimize systematic errors which may arise due to aerosol scattering and instrumentrelated effects.

The equation used to obtain the $\mathrm{XCH}_{4}$ reads as follows:

$\mathrm{XCH}_{4}=\frac{\left[\mathrm{CH}_{4}\right]_{\mathrm{GOSAT}}}{\left[\mathrm{CO}_{2}\right]_{\mathrm{GOSAT}}} \times \mathrm{XCO}_{2 \text { modeled }}$.

The proxy retrieval algorithms considered herein use different $\mathrm{XCO}_{2}$ model fields. The OCPR (OCO-Proxy) version 4 retrieval algorithm (Parker et al., 2011) from UL, developed under the ESA GHG-CCI initiative, derives the columnaveraged mole fractions of $\mathrm{CO}_{2}$ from the LMDZ model ((Chevallier et al., 2010); MACC-II $\mathrm{CO}_{2}$ fields, optimized for the whole period until the end of 2011). The RemoTeC Proxy algorithm (version 1.9/2.0) (Schepers et al., 2012) uses modelled $\mathrm{CO}_{2}$ total columns obtained from CarbonTracker (Peters et al., 2007) version 2013, with optimized $\mathrm{CO}_{2}$ fields for 2009-2012. Perturbations in the optical path will mostly cancel out when taking the ratio $\frac{\left[\mathrm{CH}_{4}\right]_{\mathrm{GOSAT}}}{\left[\mathrm{CO}_{2}\right]_{\mathrm{GOSAT}}}$ of the two measurements. However, Eq. (1) implies that errors in the modelled $\mathrm{CO}_{2}$ columns propagate directly into the derived $\mathrm{XCH}_{4}$. The quality of the latter depends thus on the accuracy of the modelled $\mathrm{CO}_{2}$ fields.

The third GOSAT $\mathrm{XCH}_{4}$ data set used in this study is the RemoTeC FP version 2.1 from SRON/KIT (Butz et al., 2011). The $\mathrm{CH}_{4}$ and $\mathrm{CO}_{2}$ columns are retrieved simultaneously with three effective aerosol parameters (amount, size, and height) from GOSAT-FTS measure- 


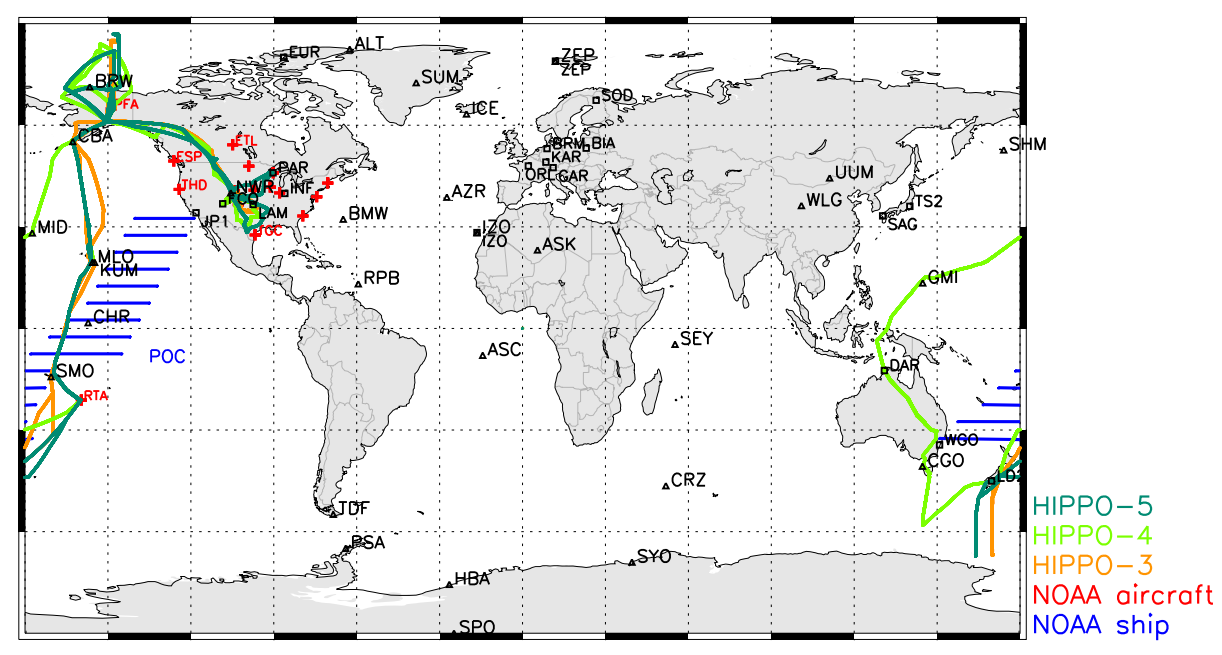

Figure 1. Observation data map indicating the locations of NOAA surface stations used in the inversions (triangle symbols; see also Table T1 in the Supplement). The squares indicate the TCCON station locations. Some of the NOAA and TCCON stations are co-located. The regions covered by NOAA ship cruises (labelled as POC) are displayed through the horizontal blue lines, which indicate the longitudinal range within each $5^{\circ}$ latitude band. In addition, we show the NOAA aircraft profile locations (red crosses), and the HIPPO 3-5 transects used for validation.

ments at the oxygen $\left(\mathrm{O}_{2}\right)$ A-band around 0.76 microns $(\mu \mathrm{m})$, the $\mathrm{CH}_{4}$ and $\mathrm{CO}_{2}$ absorption bands around $1.6 \mu \mathrm{m}$, and the strong $\mathrm{CO}_{2}$ absorption band around $2.0 \mu \mathrm{m}$. Dividing the $\mathrm{CH}_{4}$ column by the dry-air column from the European Centre for Medium-Range Weather Forecast (ECMWF) ERAInterim data yields the $\mathrm{CH}_{4}$ dry-air mixing ratios $\left(\mathrm{XCH}_{4}\right)$. The full physics approach does not require a proxy $\mathrm{CO}_{2}$ field; instead, the amount of sunlight scattering is estimated directly, together with the $\mathrm{XCH}_{4}$, from the measured spectra. However, this method can only account for a fraction of the total scattering (Butz et al., 2011). A further trade-off is the lower tolerance to cloud cover (i.e. the method requires a stricter cloud filter). Possible biases in the satellite data are corrected using $\mathrm{XCH}_{4}$ observations from the TCCON (Wunch et al., 2010) as anchor points.

The filter settings for the GOSAT SRON FP retrievals follow the approach of Butz et al. (2011). We use only observations taken over land (no sun glint ocean data) that have been screened for clouds. Scenario S1-GOSAT-SRON-FP also assimilates M-gain data (recorded over highly reflective land surfaces). There are considerable differences in the total accepted pixel counts for the FP vs. the GOSAT proxy methods. Furthermore, GOSAT has a generally much sparser spatial sampling (due to the FTS integration time) compared to SCIAMACHY. Table 4 reports the total number of satellite data points that were used in each scenario (see also Fig. 4).

\subsection{The SCIAMACHY retrievals}

The SCIAMACHY Iterative Maximum A Posteriori (IMAP) version 5.5 retrievals used in this study (Frankenberg et al., 2011) are calculated by the proxy method outlined above.
Variations in the $\mathrm{CO}_{2}$ atmospheric columns are accounted for through the use of modelled CarbonTracker carbon dioxide fields (Frankenberg et al., 2011). Problems with the detector on the SCIAMACHY instrument occurred unexpectedly at the end of 2005, and led to a considerable degradation of the instrument performance in the $1.6 \mu \mathrm{m}$ region relevant for $\mathrm{CH}_{4}$ retrievals. The main feature of the IMAP v5.5 algorithm that set it apart from its predecessor, version 5.0 (Frankenberg et al., 2008), is the extension of the time series beyond 2005 , using a coherent, uniform pixel mask for the entire retrieval period, so as to minimize the impact of pixel degradation (Frankenberg et al., 2011). The pixel deterioration remains visible in the IMAP v5.5 retrievals (higher noise levels are noticeable from November 2005). Nonetheless, comparisons with measurements at NOAA surface sites indicate relatively good consistency of the satellite data time series (Frankenberg et al., 2011). There remain some systematic differences between IMAP v5.5 and v5.0 retrievals (Frankenberg et al., 2011; Bergamaschi et al., 2013a). Following Bergamaschi et al. (2013a), we use a re-processed version of the IMAP v5.5 retrievals. This version includes CarbonTracker release $2010 \mathrm{CO}_{2}$ fields for the year 2009, while $\mathrm{CO}_{2}$ fields for years 2010 through 2012 are based on nonoptimized TM5 forward model runs using optimized $\mathrm{CO}_{2}$ emissions from previous years (Bergamaschi et al., 2013a).

We assimilate only satellite data over land between $50^{\circ} \mathrm{N}$ and $50^{\circ} \mathrm{S}$. We also discard all pixels whose average surface elevation is not within $250 \mathrm{~m}$ of the TM5 model surface height (Bergamaschi et al., 2009, 2013a). To avoid spurious outliers that may have a large impact on the inversion, we filter out any SCIAMACHY or GOSAT $\mathrm{XCH}_{4}$ retrievals of 


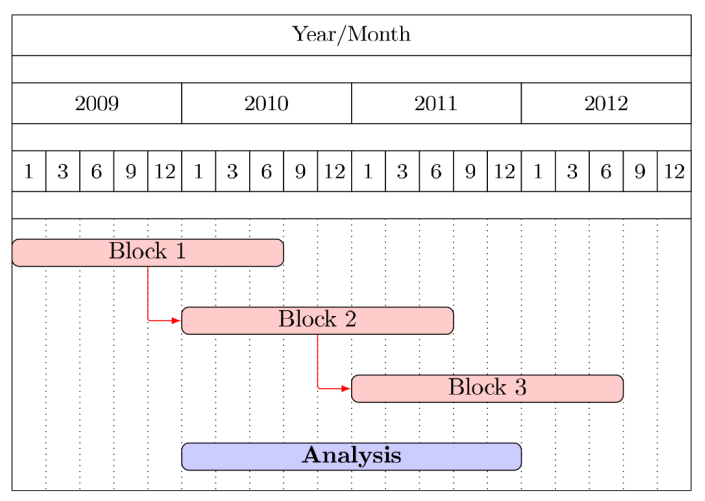

Figure 2. The inversion settings, as described in Sect. 3.2. Inversion blocks 2 and 3 start on 1 January 2010 and 1 January 2011, respectively, from the optimized 3-D $\mathrm{CH}_{4}$ fields calculated by the previous block.

less than $1500 \mathrm{nmol} \mathrm{mol}^{-1}$ (henceforth abbreviated as ppb), or larger than $2500 \mathrm{ppb}$.

A SCIAMACHY pixel covers a ground area of $30 \mathrm{~km}$ (along track) times $60 \mathrm{~km}$ (across track), whereas TANSOFTS has a ground pixel resolution of $10.5 \mathrm{~km}$ (at nadir). Single GOSAT and SCIAMACHY $\mathrm{XCH}_{4}$ retrievals are averaged on a regular (longitude $\times$ latitude) $1^{\circ} \times 1^{\circ}$ grid over the individual $3 \mathrm{~h}$ assimilation time slots. The TM5 $\mathrm{XCH}_{4}$ are then obtained by vertical integration of the $3-\mathrm{D}$ modelled $\mathrm{CH}_{4}$ fields interpolated to the same $1^{\circ} \times 1^{\circ}$ grid, using the averaging kernels of the SCIAMACHY and GOSAT retrievals (Bergamaschi et al., 2009).

\subsection{The NOAA surface observations}

All inversions use high-accuracy $\mathrm{CH}_{4}$ dry-air mole fraction measurements from a subset of 30 NOAA ESRL sites (Dlugokencky et al., 2013), globally distributed as shown in Fig. 1. Due to the coarse $6^{\circ} \times 4^{\circ}$ resolution of the model, we include only marine and continental background sites. Other locations, e.g. located near the coast or strongly influenced by sub-grid local sources, are excluded from the assimilation. Moreover, the list contains only sites with sufficient data coverage for 2010-2011. The NOAA surface measurements are calibrated against the NOAA $2004 \mathrm{CH}_{4}$ standard scale, or, equivalently, the World Meteorological Organization Global Atmosphere Watch (WMO GAW) $\mathrm{CH}_{4}$ mole fraction scale (Dlugokencky et al., 2005).

\subsection{Measurement data used for validation}

\subsubsection{NOAA observations}

The simulated $\mathrm{CH}_{4}$ mixing ratios from all inversions are evaluated against independent observations which have not been assimilated. First, modelled $\mathrm{CH}_{4}$ mixing ratios are compared against NOAA ship cruise data acquired in 2010 and
2011. These observations allow us to evaluate the simulated concentrations in the marine boundary layer, downwind of continental sources. Further important validation data sources are the NOAA aircraft-based vertical profiles (across North America and the Pacific Ocean, http://www. esrl.noaa.gov/gmd/ccgg/aircraft/index.html, and Fig. 1), to validate the modelled $\mathrm{CH}_{4}$ vertical gradients in the troposphere.

\subsubsection{HIPPO aircraft campaigns}

Simulated $\mathrm{CH}_{4}$ fields are also validated against campaigns 3, 4 and 5 of the HIPPO program (Wofsy, 2011). The three campaigns were run during March-April 2010 (HIPPO-3), JuneJuly 2011 (HIPPO-4), and August-September 2011 (HIPPO5), for the most part over the Pacific Ocean (see Fig. 1), but also partially above North America (between $87^{\circ} \mathrm{N}$ and $67^{\circ} \mathrm{S}$ ). The HIPPO data consist of continuous profiles between ca. $150 \mathrm{~m}$ and $8500 \mathrm{~m}$ altitude. Several profiles extend up to $14 \mathrm{~km}$ altitude. For details on the measurement process, which makes use of a quantum cascade laser spectrometer (QCLS), the reader is directed to Kort et al. (2012). In addition, air samples collected using the NOAA Programmable Flask Package were taken during the HIPPO campaigns. Comparison of QCLS measurements and NOAA flask samples taken within the same $10 \mathrm{~s}$ interval showed a small bias in the HIPPO data which has been accounted for in our validation (see Fig. 11 and the Supplement): 6 ppb for HIPPO-3, $4.5 \mathrm{ppb}$ for HIPPO-4, and 5.2 ppb for HIPPO-5.

\subsubsection{TCCON $\mathrm{XCH}_{4}$ retrievals}

TCCON measures dry-air column-averaged mole fractions of atmospheric $\mathrm{CH}_{4}$ at several sites across the globe (Table T2 in the Supplement) using FTS. The TCCON $\mathrm{XCH}_{4}$ observations have an uncertainty of $7 \mathrm{ppb}$, and a relative repeatability of $0.2 \%$ (Wunch et al., 2010). Only stations with sufficient data coverage during 2010-2011 are used for the validation. The modelled $\mathrm{XCH}_{4}$ at the TCCON site locations were calculated using prior TCCON profiles and averaging kernels (Rodgers and Connor, 2003).

\section{Modelling}

\subsection{Inverse modelling with TM5-4DVAR}

We estimate the monthly averages of $\mathrm{CH}_{4}$ surface fluxes between January 2010 and December 2011 using the TM54DVAR inverse modelling system (Meirink et al., 2008b). We also incorporate the further developments described in Bergamaschi et al. $(2009,2010)$. The statistical best fit of the model-generated 3-D $\mathrm{CH}_{4}$ fields and observations is 

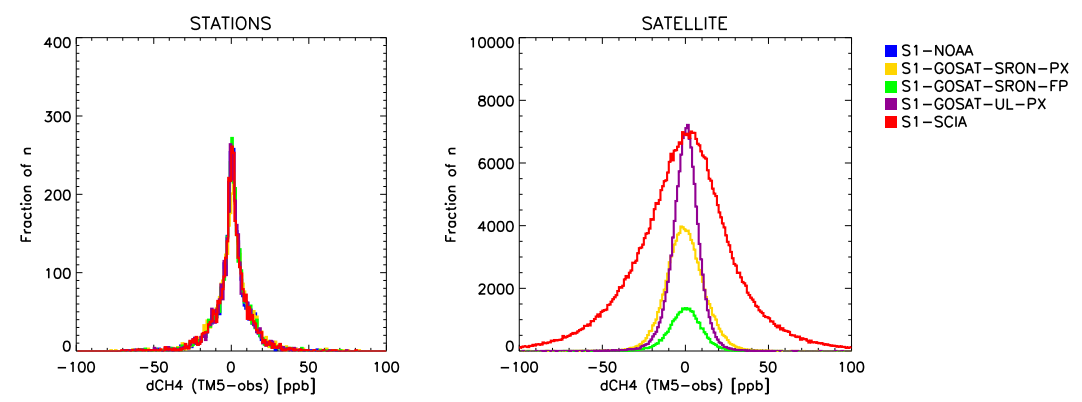

Figure 3. Frequency distributions of model-observation residuals $\left(\mathrm{dCH}_{4}\right)$ for satellite and station data (2010-2011). Both station and satellite data are distributed across 1 ppb bins. The total number of surface measurements or retrievals is denoted by $n$. The bias and root mean square (rms) of each inversion are shown in Table 4.

achieved by minimization of the following cost functional:

$$
\begin{aligned}
\mathcal{J}(\boldsymbol{x}) & =\frac{1}{2}\left(\boldsymbol{x}-\boldsymbol{x}_{\mathrm{B}}\right)^{\mathrm{T}} \mathbf{B}^{-1}\left(\boldsymbol{x}-\boldsymbol{x}_{\mathrm{B}}\right) \\
& +\frac{1}{2} \sum_{i=1}^{n}\left(\mathcal{H}_{i}(\boldsymbol{x})-\boldsymbol{y}_{i}\right)^{\mathrm{T}} \mathbf{R}_{i}^{-1}\left(\mathcal{H}_{i}(\boldsymbol{x})-\boldsymbol{y}_{i}\right) .
\end{aligned}
$$

Here $\boldsymbol{x}=\left(x_{\mathrm{conc}}, x_{\mathrm{em}}, s\right)$ is the state vector, which comprises the initial $\mathrm{CH}_{4}$ fields at the beginning of each inversion series $x_{\text {conc }}$, the monthly average emissions $x_{\mathrm{em}}$, and the bias parameters $s$ (Bergamaschi et al., 2009, 2013a). The observations are denoted by $\mathbf{y}$, while $\mathcal{H}(\boldsymbol{x})$ is the corresponding model simulation. Finally, $\mathbf{B}$ and $\mathbf{R}_{i}$ are the parameter and observation error covariance matrices, where the index $i$ indicates the assimilation window (set to $3 \mathrm{~h}$ ). We ensured a posteriori $\mathrm{CH}_{4}$ emissions were positive through the application of a "semi-lognormal" probability density function (PDF) for the a priori emissions $\left(x_{\mathrm{em}}\right)_{\mathrm{B}}$ (Bergamaschi et al., 2009, 2010). This particular choice of a priori PDF introduces a non-linearity in Eq. (2). The 4DVAR functional $\mathcal{J}$ in Eq. (2) is minimized using the algorithm M1QN3 (Gilbert and Lemaréchal, 1989). The adjoint model (Meirink et al., 2008b; Krol et al., 2008) allows for an efficient computation of the gradient of $\mathcal{J}$ during the minimization process.

TM5 is an offline transport model (Krol et al., 2005) driven by the ERA-Interim re-analysis meteorological data (Dee et al., 2011) from ECMWF. We use the standard TM5 version (cycle 1), with a global horizontal resolution of $6^{\circ} \times 4^{\circ}$ (longitude-latitude), and 25 hybrid pressure vertical layers.

\subsection{Inversion settings}

The prior emission inventories are identical to those used by Bergamaschi et al. (2013a). We independently optimize four groups of $\mathrm{CH}_{4}$ emissions: wetlands, rice, biomass burning, and other remaining sources (Bergamaschi et al., 2010, 2013a). A priori uncertainties for each emission category are set to $100 \%$ (per model grid cell and month), with the exception of the "remaining sources" whose uncertainty is set to $50 \%$. Wetland, rice, and biomass burning emissions are assumed to be uncorrelated in time, to allow the maximum flexibility when optimizing their seasonal variation. As in Bergamaschi et al. (2010), the temporal correlation of the remaining emissions - assumed to have little seasonal variation - is set to 9.5 months. A Gaussian function of the spatial distance between model grid cells is used to model the spatial emission error correlations, using a correlation length of $500 \mathrm{~km}$, for all emission categories and all scenarios. Horizontal error correlations in the initial $\mathrm{CH}_{4}$ fields are modelled using a Gaussian distance of $500 \mathrm{~km}$, while error correlations in the vertical direction are described by the National Meteorological Center (NMC) method (Parrish and Derber, 1992; Meirink et al., 2008a). For the satellite data, the reported error is taken as the measurement uncertainty. For the surface observations we prescribe a measurement uncertainty of $3 \mathrm{ppb}$, while also taking into account the model representation error, estimated from local emissions and 3-D gradients of simulated $\mathrm{CH}_{4}$ mixing ratios (Bergamaschi et al., 2010).

In all inversions the tropospheric $\mathrm{CH}_{4}$ sink is simulated using hydroxyl $(\mathrm{OH})$ radical fields from a TM5 full chemistry run using the Carbon Bond Mechanism 4 optimized based on methyl chloroform measurements (Bergamaschi et al., 2009, 2010, 2013a). The lifetime of $\mathrm{CH}_{4}$ is calculated at 10.1 years (total $\mathrm{CH}_{4}$ vs. tropospheric $\mathrm{OH}$ ). The fifth generation European Centre Hamburg general circulation model (ECHAM5) Modular Earth Submodel System version 1 (MESSy1) (Jöckel et al., 2006) is used to parameterize the stratospheric chemical destruction of $\mathrm{CH}_{4}$ by $\mathrm{OH}$, $\mathrm{Cl}$, and $\mathrm{O}\left({ }^{1} \mathrm{D}\right)$, using sink averages from 1999 to 2002.

The number of optimization iterations required to minimize the cost functional (Eq. 2) increases with the length of the assimilation window. For this reason, we have split all our inversions into 18-month blocks (Fig. 2), with 6month spin-down periods (Bergamaschi et al., 2013a). Consecutive blocks overlap by 6 months. The first block starts on 1 January 2009; the third 18-month inversion block ends on 1 July 2012. The inversion for 2009 is considered as spin-up, and not further analysed in this study. The results for the 6-month spin-down periods are also not used in the analysis. A priori 3-D $\mathrm{CH}_{4}$ concentration fields for $1 \mathrm{Jan}-$ uary 2009 are taken from a $\mathrm{CH}_{4}$ inversion constrained only 


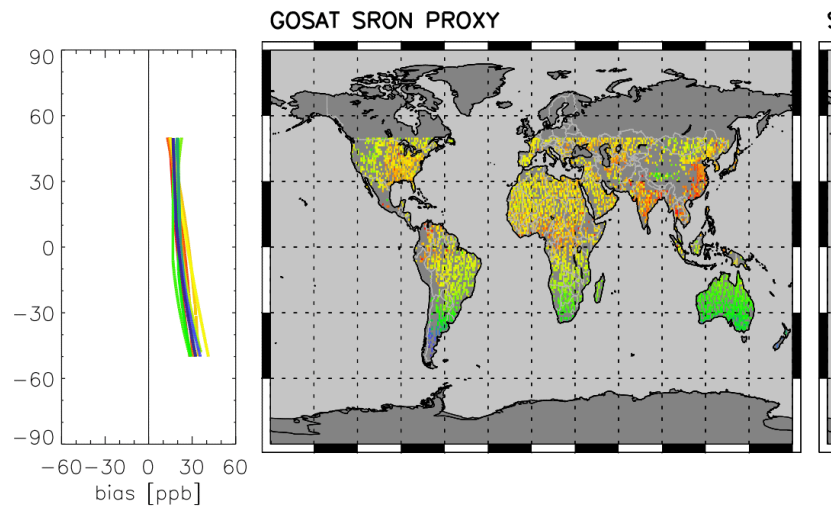

S1-GOSAT-SRON-PX
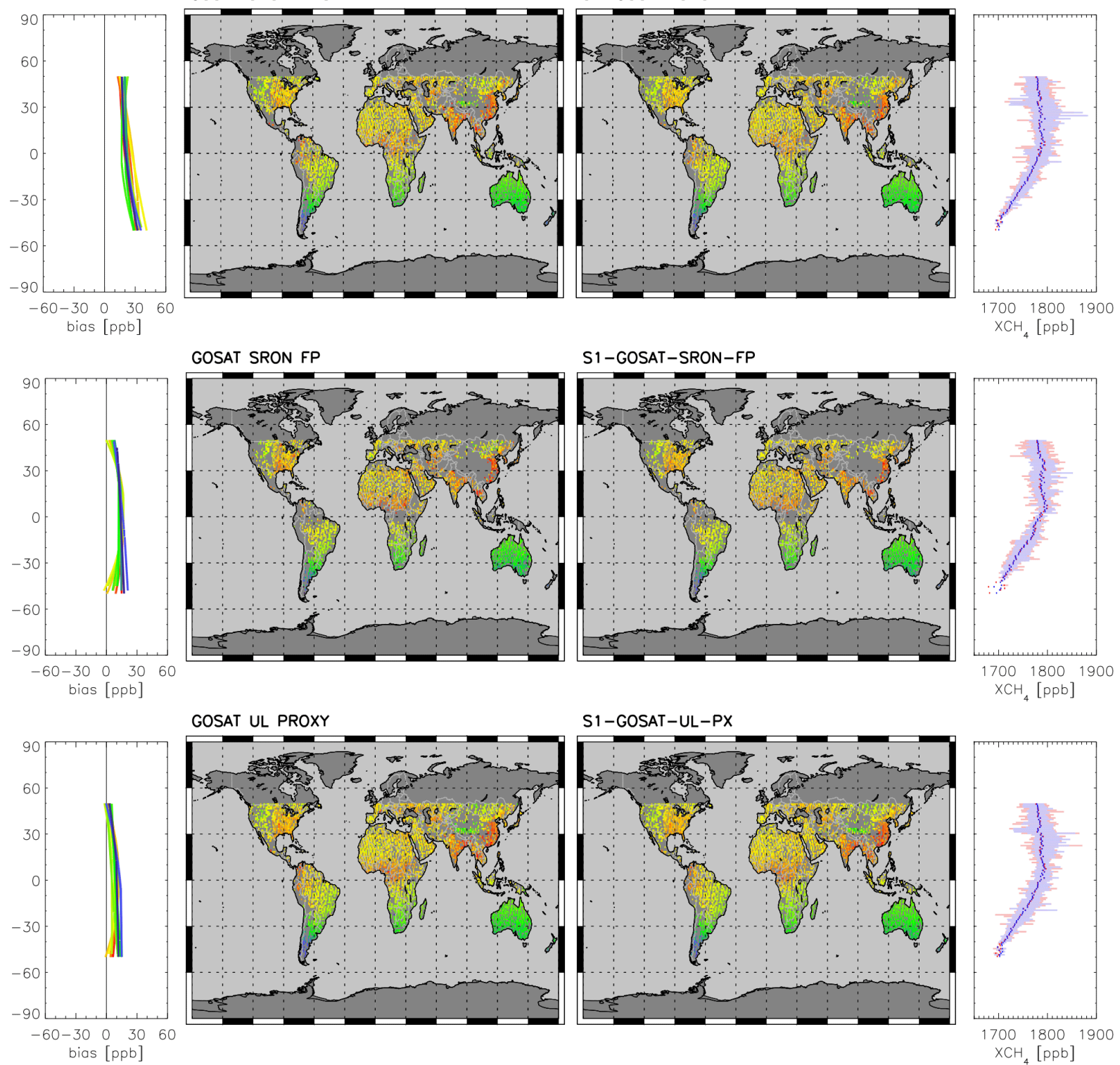

S1-GOSAT-SRON-FP
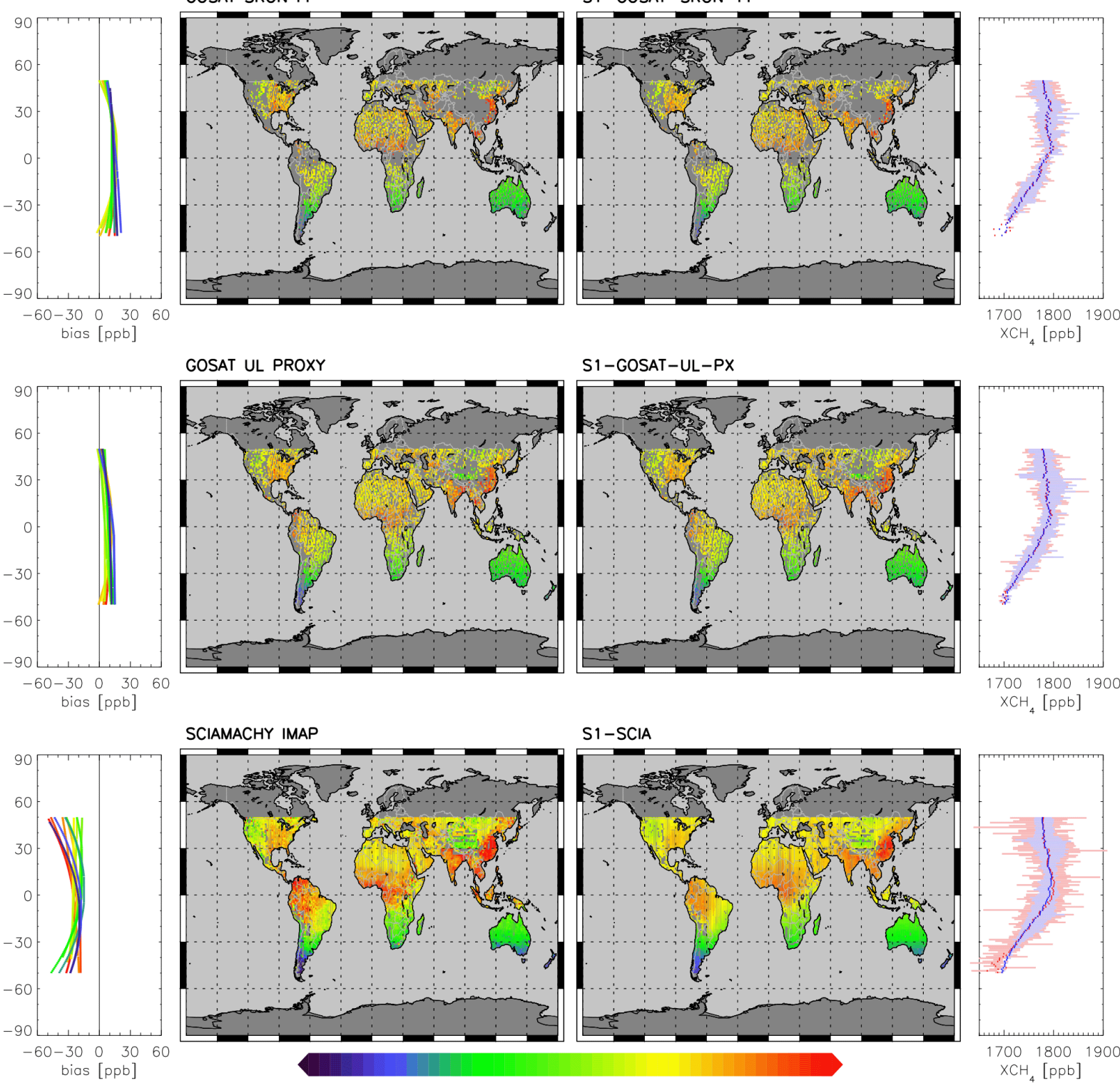

SCIAMACHY IMAP
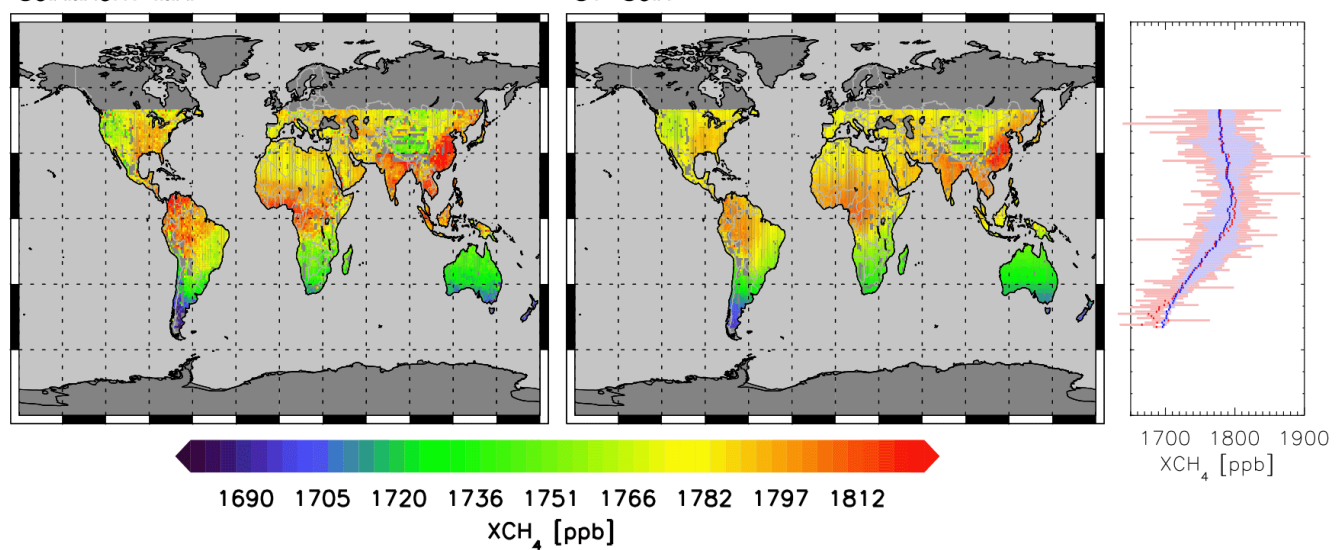

Figure 4. Column-averaged $\mathrm{CH}_{4}$ mixing ratios $\left(\mathrm{XCH}_{4}\right)$ : bias-corrected satellite retrievals vs. TM5-4DVAR. The left plots show the monthly average bias corrections (in ppb) applied to the satellite data for January 2010-December 2011. The panels on the right display the twoyear latitudinal average $\mathrm{XCH}_{4}$ values (red: satellite; blue: TM5-4DVAR) and the corresponding minimum and maximum values across the longitude. 
Table 2. Inversion scenarios.

\begin{tabular}{ll}
\hline Inversion & Assimilated observations \\
\hline S1-NOAA & NOAA ESRL surface measurements only \\
S1-GOSAT-SRON-PX & NOAA ESRL surface measurements and GOSAT RemoTeC Proxy v1.9/v2.0 XCH 4 \\
S1-GOSAT-SRON-FP & NOAA ESRL surface measurements and GOSAT RemoTeC FP v2.1 XCH \\
S1-GOSAT-UL-PX & NOAA ESRL surface measurements and GOSAT OCPR v4.0 XCH \\
S1-SCIA & NOAA ESRL surface measurements and SCIAMACHY IMAP v5.5 XCH \\
\hline S2-GOSAT-SRON-FP & as S1-GOSAT-SRON-FP, with a constant bias correction instead of 2nd order polynomial \\
S3-GOSAT-SRON-FP & as S1-GOSAT-SRON-FP, with a smooth bias correction \\
S2-GOSAT-UL-PX & as S1-GOSAT-UL-PX, with a constant bias correction instead of 2nd order polynomial \\
S3-GOSAT-UL-PX & as S1-GOSAT-UL-PX, with a smooth bias correction \\
\hline
\end{tabular}

Table 3. Inversion settings: current study vs. Monteil et al. (2013).

\begin{tabular}{|c|c|c|}
\hline & Current study & Monteil et al. (2013) \\
\hline Prior PDFs & Semi-lognormal & $\begin{array}{l}\text { Gaussian (may result in negative a posteriori } \\
\text { emissions) }\end{array}$ \\
\hline \multirow[t]{4}{*}{ Satellite retrievals } & ENVISAT/SCIAMACHY IMAP v5.5 & ENVISAT/SCIAMACHY IMAP v5.5 \\
\hline & $\begin{array}{l}\text { GOSAT/TANSO-FTS RemoTeC Proxy } \\
\text { v1.9/2.0 }\end{array}$ & GOSAT/TANSO-FTS RemoTeC Proxy v1.0 \\
\hline & $\begin{array}{l}\text { GOSAT/TANSO-FTS RemoTeC FP } \\
\text { v2.1 }\end{array}$ & GOSAT/TANSO-FTS RemoTeC FP v1.0 \\
\hline & GOSAT/TANSO-FTS OCPR v4.0 & \\
\hline \multirow[t]{3}{*}{ Bias correction } & $\begin{array}{l}\text { Function of latitude and month, opti- } \\
\text { mized in the inversion (for all satellite } \\
\text { products). }\end{array}$ & $\begin{array}{l}\text { GOSAT RemoTeC FP v1.0: Correction by a sin- } \\
\text { gle coefficient (1.0037). }\end{array}$ \\
\hline & & $\begin{array}{l}\text { GOSAT RemoTeC Proxy v1.0: no bias correc- } \\
\text { tion applied. }\end{array}$ \\
\hline & & $\begin{array}{l}\text { SCIAMACHY IMAP v5.5: Constant factor, plus } \\
\text { seasonally varying bias correction term based on } \\
\text { specific humidity (Houweling et al., 2014). }\end{array}$ \\
\hline Stratospheric sink & ECHAM5/MESSy1. & $\begin{array}{l}\text { Cambridge } 2-\mathrm{D} \text { model (Velders, 1995) with a } \\
\text { correction based on HALOE/CLAES climatol- } \\
\text { ogy applied above } 50 \mathrm{hPa} \text {. }\end{array}$ \\
\hline Tropospheric $\mathrm{OH}$ & $\begin{array}{l}\text { TM5 full chemistry run based on CBM4 } \\
\text { (see Section 3.2) }\end{array}$ & $\begin{array}{l}\text { Spivakovsky et al. (2000), with a scaling factor } \\
\text { of } 0.92 \text {. }\end{array}$ \\
\hline Satellite retrieval errors & Uses reported $\mathrm{XCH}_{4}$ errors. & $\begin{array}{l}\text { The reported GOSAT retrieval uncertainties are } \\
\text { scaled by a factor of } 1.5 \text { before the inversion. }\end{array}$ \\
\hline Emission categories & $\begin{array}{l}\text { Four categories optimized indepen- } \\
\text { dently. }\end{array}$ & Total emissions. \\
\hline $\begin{array}{l}\text { Prior emission uncer- } \\
\text { tainties }\end{array}$ & $\begin{array}{l}50-100 \% \text { per category, grid cell, and } \\
\text { month (see Sect. 3.2). }\end{array}$ & $50 \%$ per grid cell and month. \\
\hline Target period & January 2010-December 2011 & April 2009-August 2010 \\
\hline
\end{tabular}

by surface measurements (scenario S1-NOAA of Bergamaschi et al., 2013a), with the exception of scenario S1-SCIA, which uses the optimized concentrations from inversion S1SCIA of Bergamaschi et al. (2013a). Sixty iterations of the M1QN3 optimization algorithm are used for the cost function minimization in each inversion block for all inversions which include satellite data, and 40 iterations for S1-NOAA (which assimilates only the NOAA surface data).
Initial $\mathrm{CH}_{4}$ 3-D fields are optimized only for the first inversion block. The other two 18 month blocks start on 1 January from the optimized initial fields of the previous inversion block. This methodology guarantees a closed $\mathrm{CH}_{4}$ budget across the entire inversion period, i.e. total sources minus total sinks yield the variation in the global $\mathrm{CH}_{4}$ burden. Additionally, the spin-down periods ensure that surface fluxes for 2010-2011 are constrained by all available observations for at least 6 months after emission. 
Table 4. Statistics for inversions S1-NOAA through S1-SCIA: NOAA surface measurements (left) and satellite data (right). See Fig. 3 for the frequency distributions of fit residuals.

\begin{tabular}{lccccccc}
\hline Inversion & \multicolumn{3}{c}{ NOAA ground stations } & & \multicolumn{3}{c}{ Satellite } \\
\cline { 2 - 4 } \cline { 7 - 8 } & $n$ & Bias [ppb] & rms [ppb] & & & Bias [ppb] & rms [ppb] \\
\hline S1-NOAA & 3418 & 0.2 & 11.5 & & - & - & - \\
S1-GOSAT-SRON-PX & 3418 & 0.3 & 12.4 & & 106854 & -0.3 & 9.2 \\
S1-GOSAT-SRON-FP & 3418 & 0.4 & 12.1 & & 31201 & -0.3 & 10.4 \\
S1-GOSAT-UL-PX & 3418 & 0.4 & 11.8 & & 129916 & -0.1 & 8.9 \\
S1-SCIA & 3418 & 0.3 & 12.0 & & 432008 & -0.9 & 32.3 \\
\hline
\end{tabular}

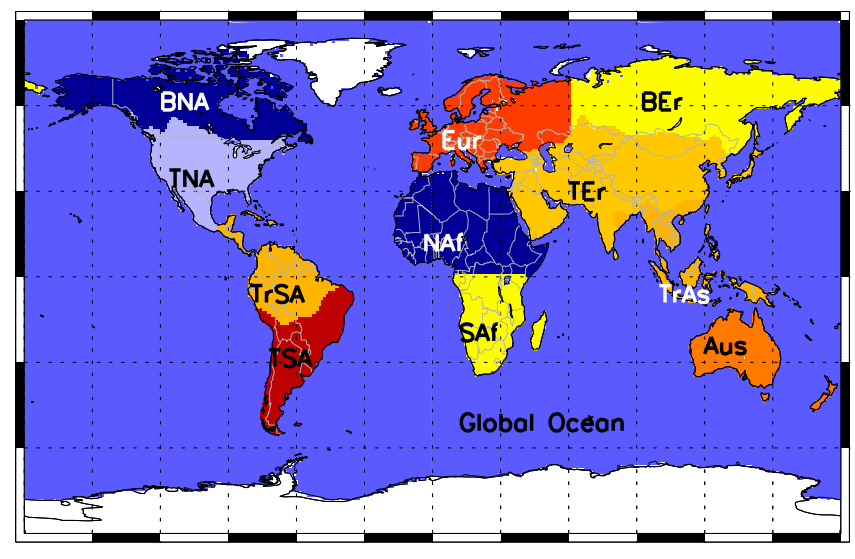

Figure 5. The TRANSCOM emission regions used in this study (at $1^{\circ} \times 1^{\circ}$ resolution). The land regions are labelled as follows: boreal North America (BNA), temperate North America (TNA), tropical South America (TrSA), temperate South America (TSA), Europe (Eur), North Africa (NAf), South Africa (SAf), boreal Eurasia (BEr), temperate Eurasia (TEr), tropical Asia (TrAs), and Australasia (Aus). White areas (ice) are not assigned to any region.

The inversion scenarios considered in this study are summarized in Table 2. Scenario S1-NOAA is intended as a baseline for all the other inversions; it uses only NOAA ESRL surface station data. Scenarios S1-GOSAT-SRON-PX, S1GOSAT-SRON-FP, and S1-GOSAT-UL-PX assimilate both NOAA surface data and GOSAT $\mathrm{XCH}_{4}$ retrievals, whereas S1-SCIA uses SCIAMACHY retrievals and NOAA surface observations. The S1-satellite inversions make use of a second-order polynomial bias correction scheme that is a function of latitude and month (Bergamaschi et al., 2009, 2013a). Table 3 lists the main technical differences between the inversion system considered in the current study and the set-up used by Monteil et al. (2013).

To assess the impact of the bias correction scheme on the posterior emission estimates, we have considered four additional scenarios: S2-GOSAT-SRON-FP, S3-GOSAT-SRONFP, S2-GOSAT-UL-PX and S3-GOSAT-UL-PX. These differ from S1-GOSAT-SRON-FP and S1-GOSAT-UL-PX by their bias correction scheme. Inversions S3-GOSAT-SRONFP and S3-GOSAT-UL-PX use a "smooth" bias correction
(Bergamaschi et al., 2013a): one bias parameter per degree of latitude and month, $10 \mathrm{ppb}$ prior uncertainty, and a prescribed $20^{\circ}$ latitude Gaussian error correlation length. The bias correction coefficients used for S2-GOSAT-SRON-FP and S2GOSAT-UL-PX are variable in time, but constant with latitude. The choice of bias correction scheme is not found to have a significant impact on the posterior regional emission estimates (shown in Table 5).

The aim of this study is to quantify the impact of the different satellite retrievals on the inverted $\mathrm{CH}_{4}$ fluxes and concentrations. Hence, all inversions use the same a priori emission inventories (as in Bergamaschi et al., 2013a), and identical $\mathrm{OH}$ fields. It is important to note that the surface observations act as constraints (or "anchor points") for the bias correction scheme.

\section{Results and discussion}

\subsection{Assimilation statistics}

The posterior statistics of S1-NOAA through S1-SCIA are summarized in Table 4. Figure 3 shows the frequency distributions of fit residuals (difference between model and observations). The data in Table 4 show that bias is close to zero for both surface measurements and satellite $\mathrm{XCH}_{4}$. Moreover, the model performance at the NOAA sites remains virtually identical when satellite data are assimilated: comparing the satellite-based inversions with S1-NOAA we note only a marginal increase in the bias of $0.1-0.2 \mathrm{ppb}$, and in the root mean square (rms) difference of about $0.3-0.9 \mathrm{ppb}$ (see also Fig. 3). The statistics of the three GOSAT inversions are almost identical in terms of posterior bias, standard deviation, and rms difference between retrieved and assimilated $\mathrm{XCH}_{4}$. While the large global bias in the SCIAMACHY $\mathrm{XCH}_{4}$ retrievals is, for the most part, compensated by the bias correction mechanism (Fig. 4), the average standard deviation of the posterior distribution of SCIAMACHY-TM5 fit residuals $($ sigma $=32 \mathrm{ppb})$ is much larger than that of the GOSAT inversions (sigma $=9-10$ ppb for S1-GOSATSRON-PX through S1-GOSAT-UL-PX). The significantly lower standard deviations of the fit residuals of all GOSATbased inversions demonstrate the much higher precision and 

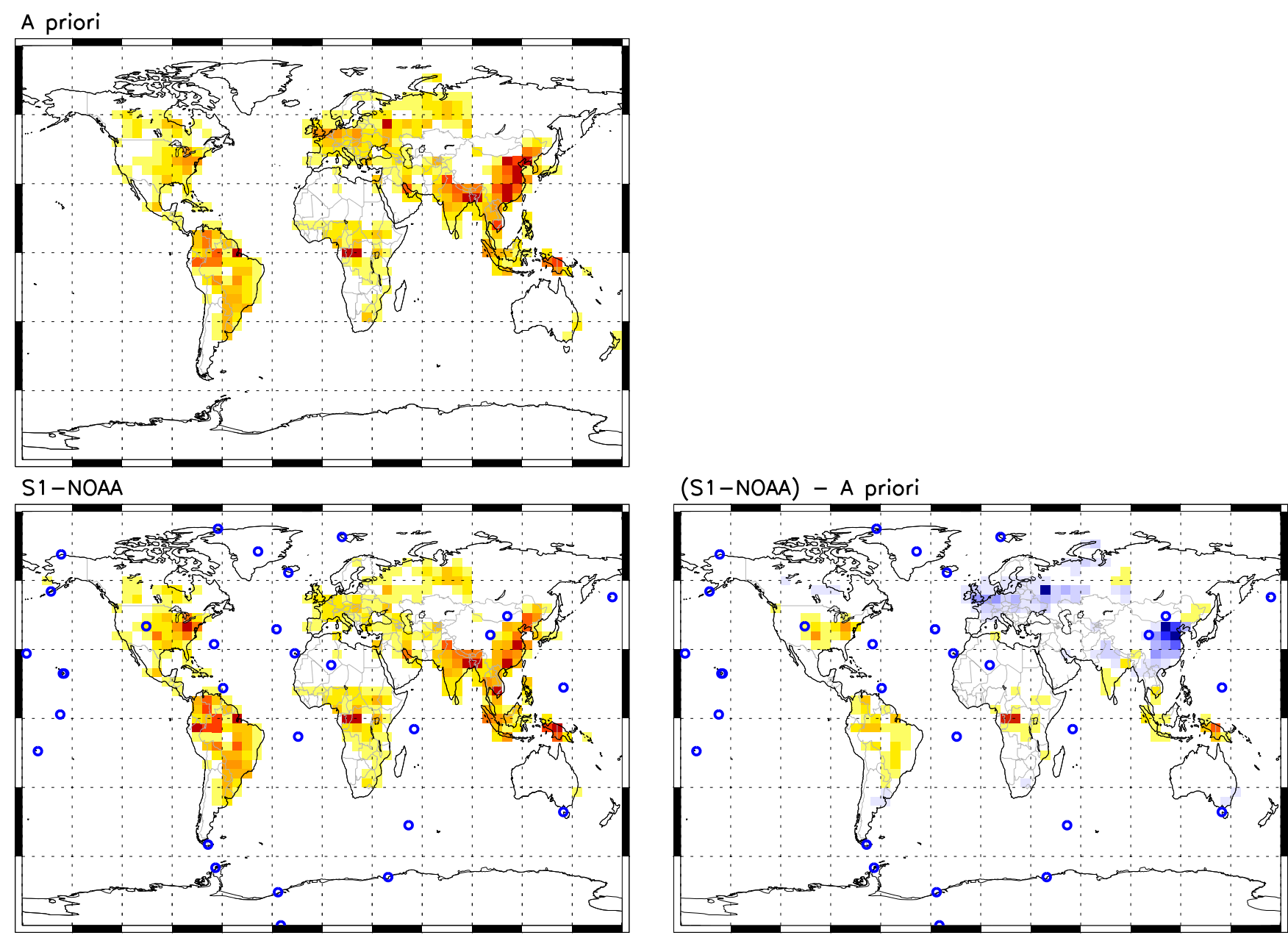

S1-GOSAT-SRON-PX

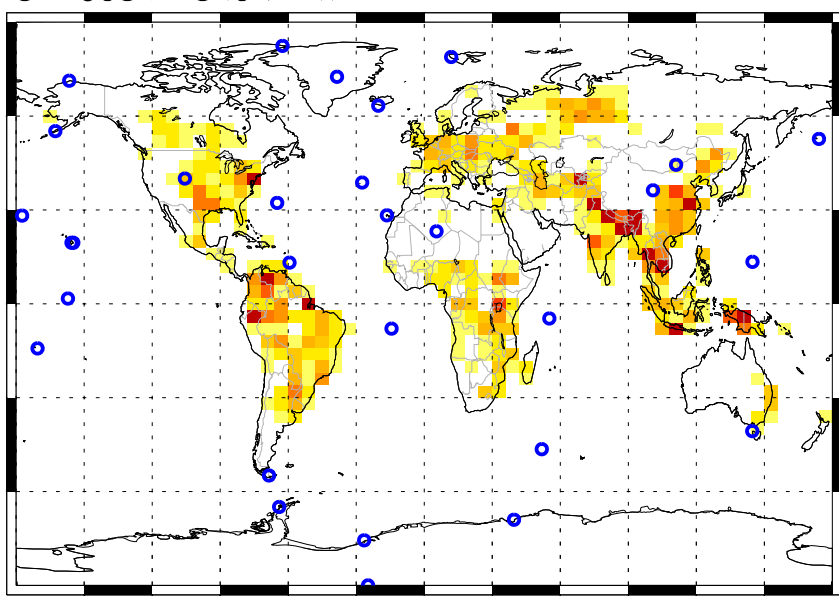

$(\mathrm{S} 1-\mathrm{GOSAT}-\mathrm{SRON}-\mathrm{PX})-(\mathrm{S} 1-\mathrm{NOAA})$

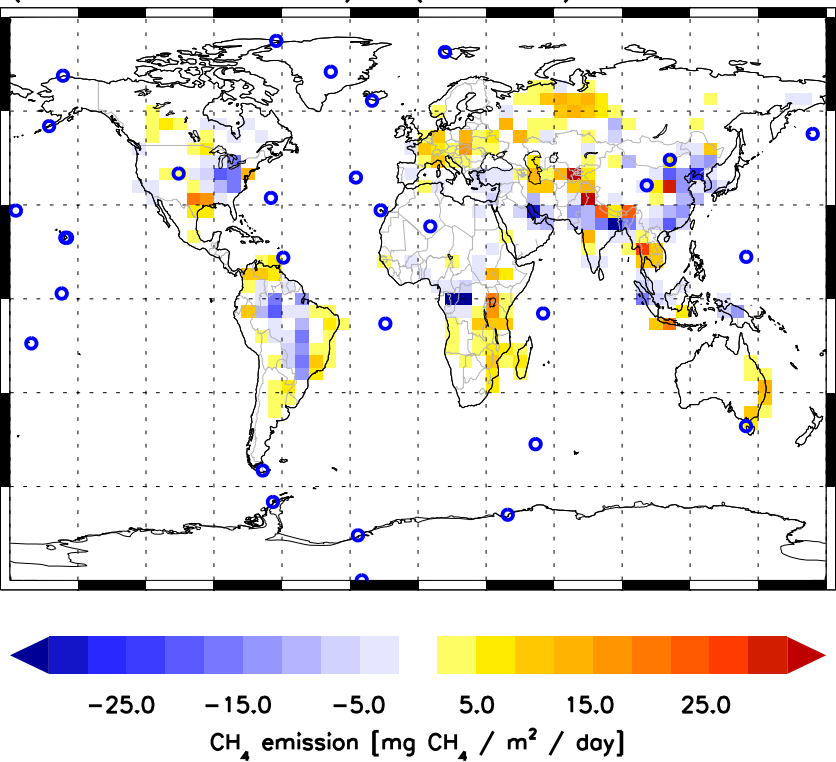

Figure 6. Left: a posteriori 2-year average emissions for S1-NOAA and S1-GOSAT-SRON-PX. The a priori emissions are shown in the topmost plot. White areas indicate grid cells with very low emissions (less than $5 \mathrm{mg} \mathrm{CH}_{4} \mathrm{~m}^{-2}$ day $^{-1}$ ). Right: for S1-NOAA the difference between posteriori and a priori emissions is shown, while for all satellite inversions the panels show the difference between the a posteriori emissions of these inversions and S1-NOAA. 

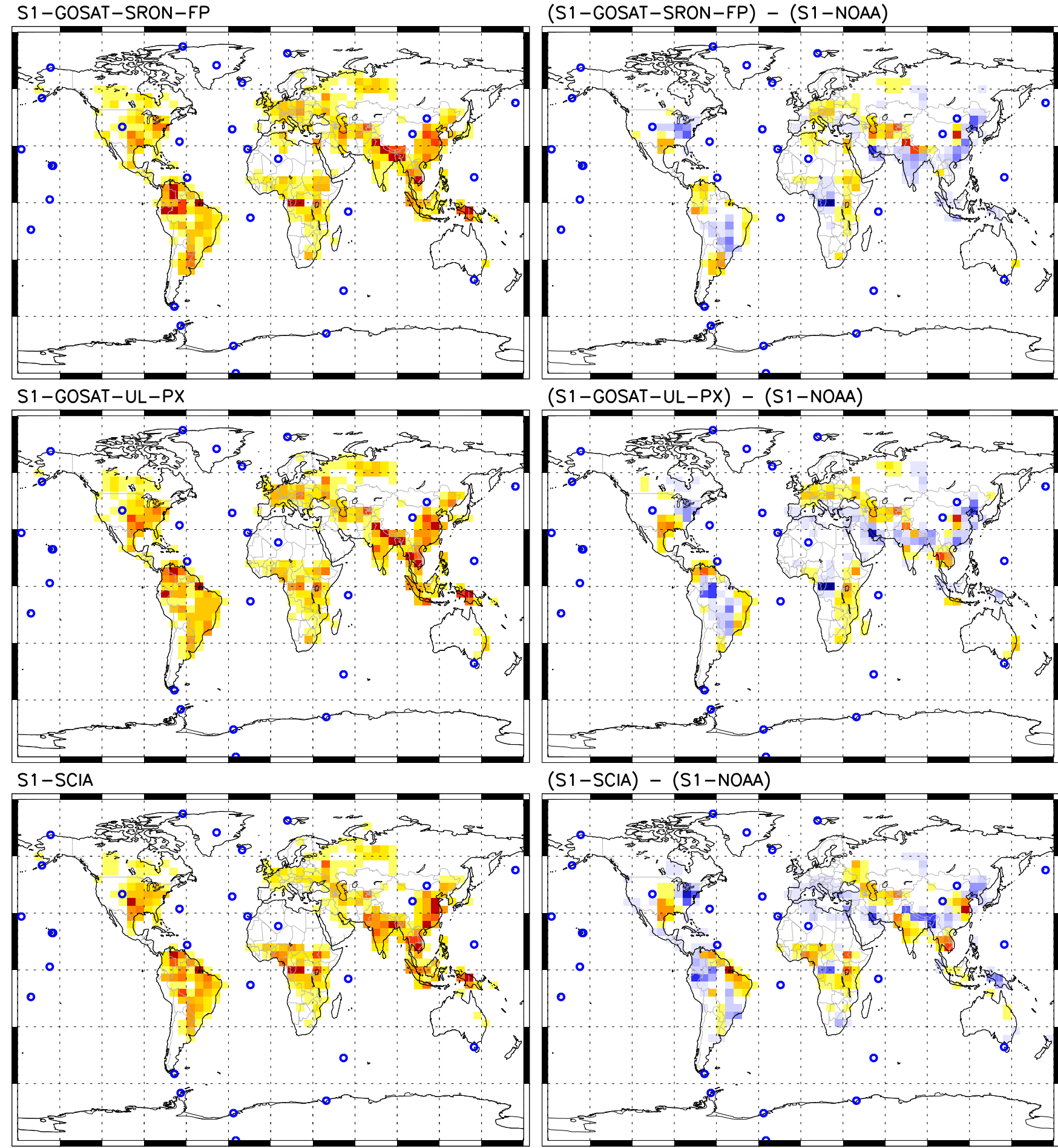

$(S 1-G O S A T-U L-P X)-(S 1-N O A A)$

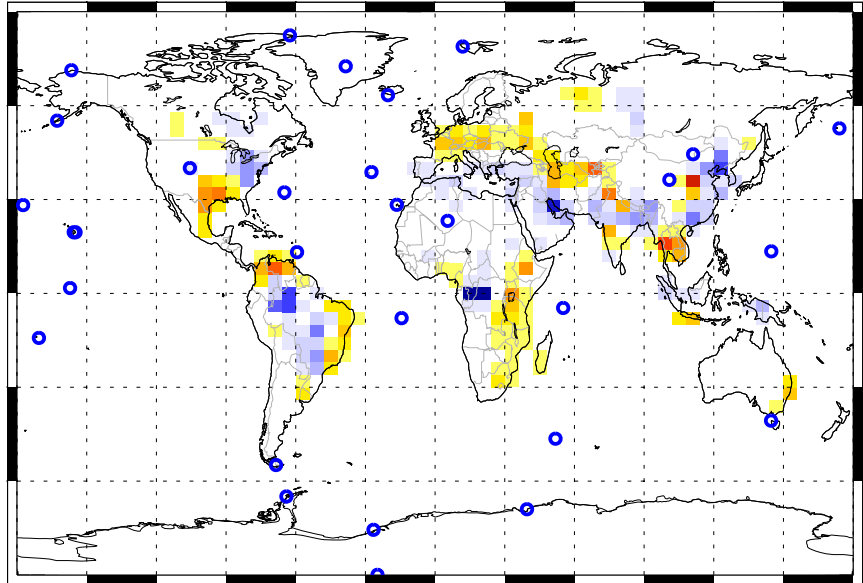

$(\mathrm{S} 1-\mathrm{SC} I A)-(\mathrm{S} 1-\mathrm{NOAA})$

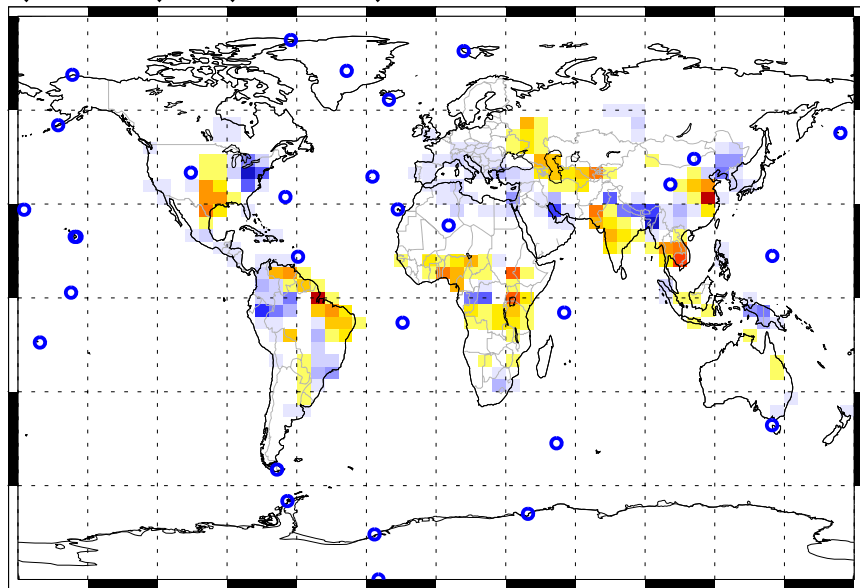

$\begin{array}{lllllllll}5.0 & 10.0 & 15.0 & 20.0 & 25.0 & 30.0 & 35.0 & 40.0 & 45.0\end{array}$ $\mathrm{CH}_{4}$ emission [mg $\mathrm{CH}_{4} / \mathrm{m}^{2} /$ day]

$\begin{array}{llllll}-25.0 & -15.0 & -5.0 & 5.0 & 15.0 & 25.0\end{array}$ $\mathrm{CH}_{4}$ emission [mg $\mathrm{CH}_{4} / \mathrm{m}^{2} /$ day]

Figure 6. Scenarios S1-GOSAT-SRON-FP, S1-GOSAT-UL-PX and S1-SCIA. 

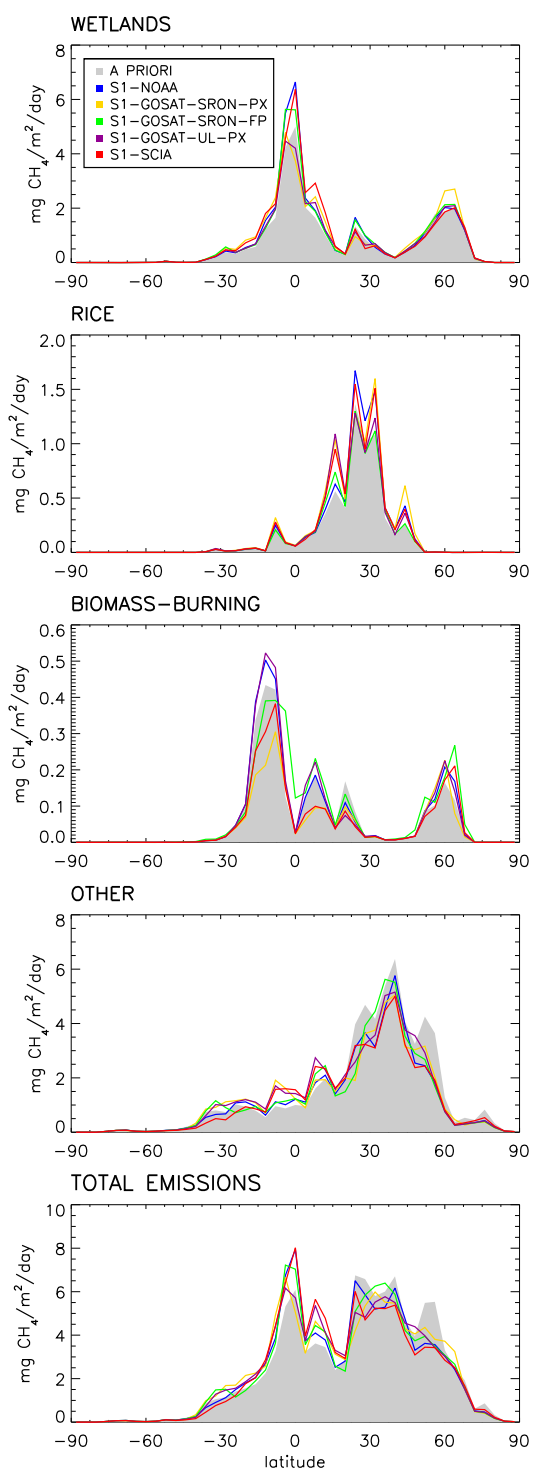

Figure 7. Two-year latitudinal averages of $\mathrm{CH}_{4}$ emissions, shown for the different source categories optimized in the inversions, and for the total emissions. The gray areas correspond to the prior emissions.

relative accuracy of the GOSAT $\mathrm{XCH}_{4}$ products (compared to the SCIAMACHY retrievals). We note that the GOSAT inversions presented by Monteil et al. (2013) yielded a higher standard deviation (14.7-15.8 ppb). Since they used a previous retrieval version (RemoTeC Proxy v1.0 and FP v1.0 $\mathrm{XCH}_{4}$ ), the lower standard deviation obtained in our study may reflect the further improvement of the GOSAT retrievals. Furthermore, the optimization of the bias correction is likely a contributing factor: while Monteil et al. (2013) applied a constant correction to the GOSAT FP retrievals before the inversion, based on the comparison with the TCCON data, they did not use any bias correction for the GOSAT proxy retrievals.

\subsection{Modelled $\mathrm{XCH}_{4}$}

Figure 4 shows the column-averaged $\mathrm{CH}_{4}$ mixing ratios for 2010-2011 (2-year averages). The bias-corrected $\mathrm{XCH}_{4}$ retrievals are plotted in the maps on the left, while the maps on the right show the assimilated $\mathrm{XCH}_{4}$. Note the much denser data coverage of the SCIAMACHY $\mathrm{XCH}_{4}$ retrievals (last row of Fig. 4) compared to that of the GOSAT products. For GOSAT, the more stringent selection criteria applied to the FP retrievals result in significantly lower pixel density than that achieved by the two proxy $\mathrm{XCH}_{4}$ retrievals (see also Table 4).

The 4DVAR assimilation system is able to capture most major regional patterns of the observed $\mathrm{XCH}_{4}$ fields, e.g. the pronounced $\mathrm{XCH}_{4}$ enhancements over South-East Asia. Over tropical South America, the agreement between retrieved and assimilated $\mathrm{XCH}_{4}$ patterns is generally better for the three GOSAT-based inversions than for SCIAMACHY (e.g. over Columbia and Venezuela). Note, however, the lower data density of the GOSAT retrievals (especially of the GOSAT FP retrievals) over those areas compared to SCIAMACHY. The different GOSAT products show very good consistency overall regarding the spatial $\mathrm{XCH}_{4}$ patterns (in particular the two GOSAT proxy retrievals), and result in only small-to-moderate calculated bias corrections (maximum 10-20 ppb), indicating good consistency with the surface observations. In contrast, the SCIAMACHY $\mathrm{XCH}_{4}$ require a significantly higher bias correction (varying with latitude by up to ca. $40 \mathrm{ppb}$ ). There are various indications that the SCIAMACHY IMAP v5.5 $\mathrm{XCH}_{4}$ have a complex bias structure (e.g. the comparison with previous IMAP v5.0 $\mathrm{XCH}_{4}$ retrievals examined by (Frankenberg et al., 2011)), which cannot be fully compensated by our polynomial bias correction. Furthermore, Houweling et al. (2014) showed recently that the bias of the SCIAMACHY IMAP v5.5 retrievals is strongly correlated with water vapour.

\subsection{A posteriori $\mathrm{CH}_{4}$ fluxes}

Figure 6 shows the spatial distribution of emissions, averaged over the 2 years (2010-2011). The maps on the left side show the a priori (top) and a posteriori fluxes. The maps on the right display the differences between a posteriori and a priori emissions for our baseline inversion S1-NOAA, and for the satellite inversions S1-GOSAT-SRON-PX through S1-SCIA the difference between the a posteriori emissions of these inversions and S1-NOAA. While the satellite inversions yield significantly different spatial emission patterns compared to the NOAA-only inversion (due to the constraints of the satellite data over the continents), they show overall good qualitative agreement across all satellite inversions. This is particularly visible in the difference plots on the right side of Fig. 6, which show similar regional emission increments relative to the NOAA-only inversion, especially over tropical Africa and the United States. While the NOAA-only inversion re- 

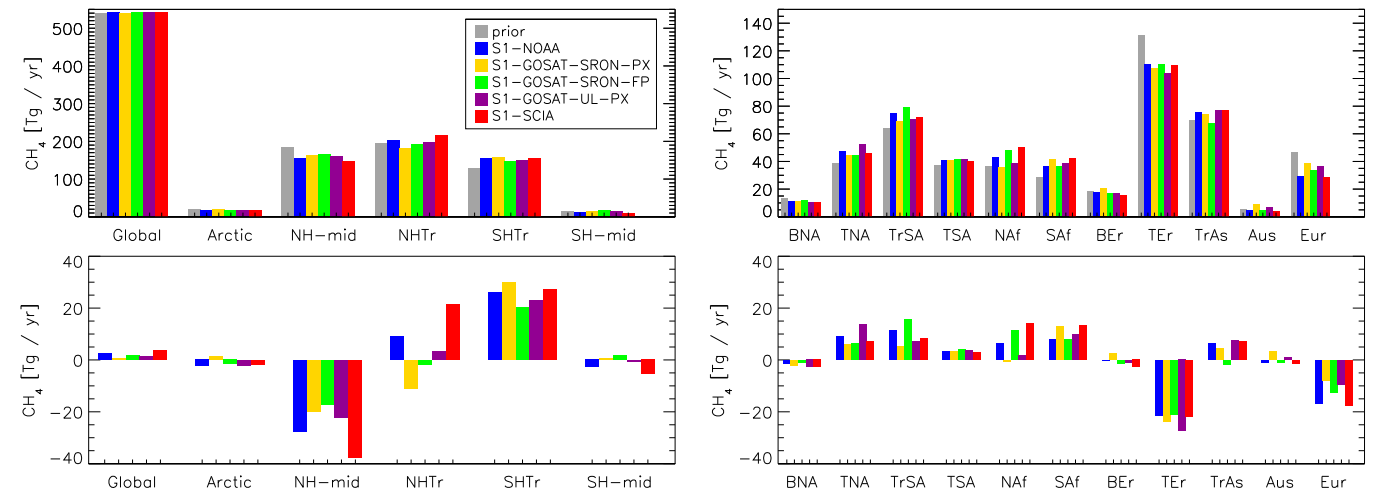

Figure 8. Average yearly $\mathrm{CH}_{4}$ emissions for the pre-defined regions. Top panels show total surface fluxes (in $\mathrm{Tg} \mathrm{CH}_{4} \mathrm{yr}^{-1}$ ), while increments from the prior are given in the bottom panels. Yearly totals are shown on the left along with surface fluxes attributed to each $30^{\circ}$ latitude band. The Antarctic region (not shown here) is estimated to be responsible for less than $0.1 \mathrm{Tg} \mathrm{yr}^{-1}$ of $\mathrm{CH}_{4}$. The two panels on the right show the TRANSCOM region emissions (see Fig. 5 for the region definitions).
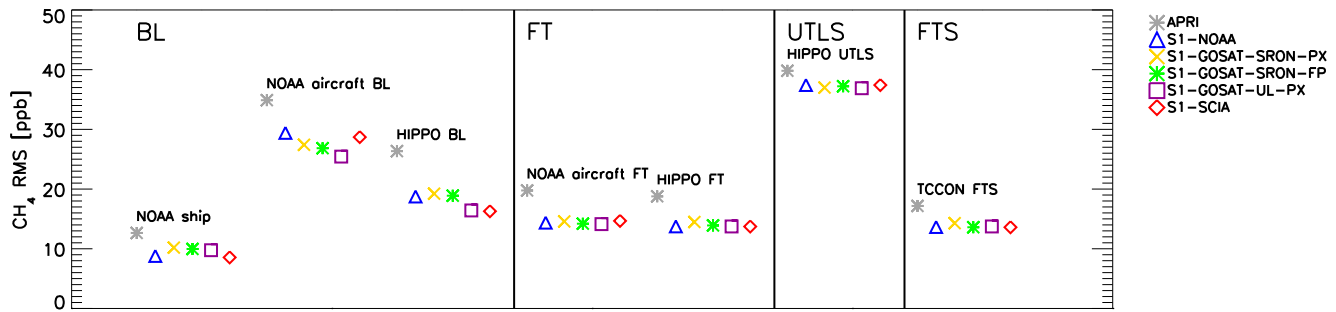

Figure 9. Validation against independent measurement data sets for all inversions. The plot shows the rms (in ppb) of differences between modelled $\mathrm{CH}_{4}$ mixing ratios, and observation data in the boundary layer ("BL"), free troposphere ("FT"), and upper troposphere/lower stratosphere ("UT/LS"). Observation data sources: NOAA shipboard samples, vertical profiles from NOAA aircraft sampling, and the HIPPO campaigns 3-5. Validation results for the Fourier Transform Spectrometer $\mathrm{CH}_{4}$ total column data from TCCON are shown in a separate panel ("FTS"). The prior (APRI) is already partly optimized (see Sect. 3.2).

sults in a significant increase of the emission hot spot over the Congo Basin (which is a prominent feature in the applied wetland inventory, see Bergamaschi et al., 2007, 2009), all satellite inversions significantly reduce the emissions from this hot spot, and instead increase the emissions in tropical East Africa (see also the "wetlands" panel in Fig. 7). Note that S1-GOSAT-SRON-FP calculates slightly lower emission rates for equatorial Africa, likely due to the absence of observations available directly over that region (Fig. 4). Especially for the NOAA-only inversion, the a posteriori $\mathrm{CH}_{4}$ fluxes over the tropics depend in large part on the choice of prior inventory. Unfortunately, their uncertainties remain very high, and the comparison of global wetland models by Melton et al. (2013) shows large discrepancies in estimated $\mathrm{CH}_{4}$ emissions among the models. The relatively consistent spatial patterns over tropical Africa found in this study for the different satellite inversions demonstrate that the satellite data combined with the inverse models provide significant constraints on the $\mathrm{CH}_{4}$ emissions from this region.

The total emission latitudinal averages (shown in the bottom panel of Fig. 7) are relatively consistent among all five scenarios. The decrease in fluxes over the temperate North- ern Hemisphere can be partly attributed to an attenuation of EDGAR anthropogenic emission hot spots over Eastern Europe, as seen in the panel labelled "other". However, there remain noticeable inter-scenario differences in the category averages, particularly for wetland and biomass-burning emissions at tropical latitudes.

Over North America, the satellite inversions result in a significant redistribution of $\mathrm{CH}_{4}$ emissions from North-East United States to the middle South. A similar spatial pattern, with significantly higher $\mathrm{CH}_{4}$ emissions over South-Central United States compared to bottom-up inventories, has recently been reported by Miller et al. (2013), and attributed by the authors of that study mainly to fossil fuel emissions. Furthermore, a recent comprehensive review by Brandt et al. (2014), which analysed a large number of bottom-up and topdown studies ranging from facility level, over regional level and up to country level, suggested a systematic underestimation of $\mathrm{CH}_{4}$ emissions from North-American natural gas systems in bottom-up inventories. Although the spatial redistribution of $\mathrm{CH}_{4}$ emissions over the United States calculated by our satellite inversions appears to be consistent with these studies, we emphasize that the applied coarse model resolu- 

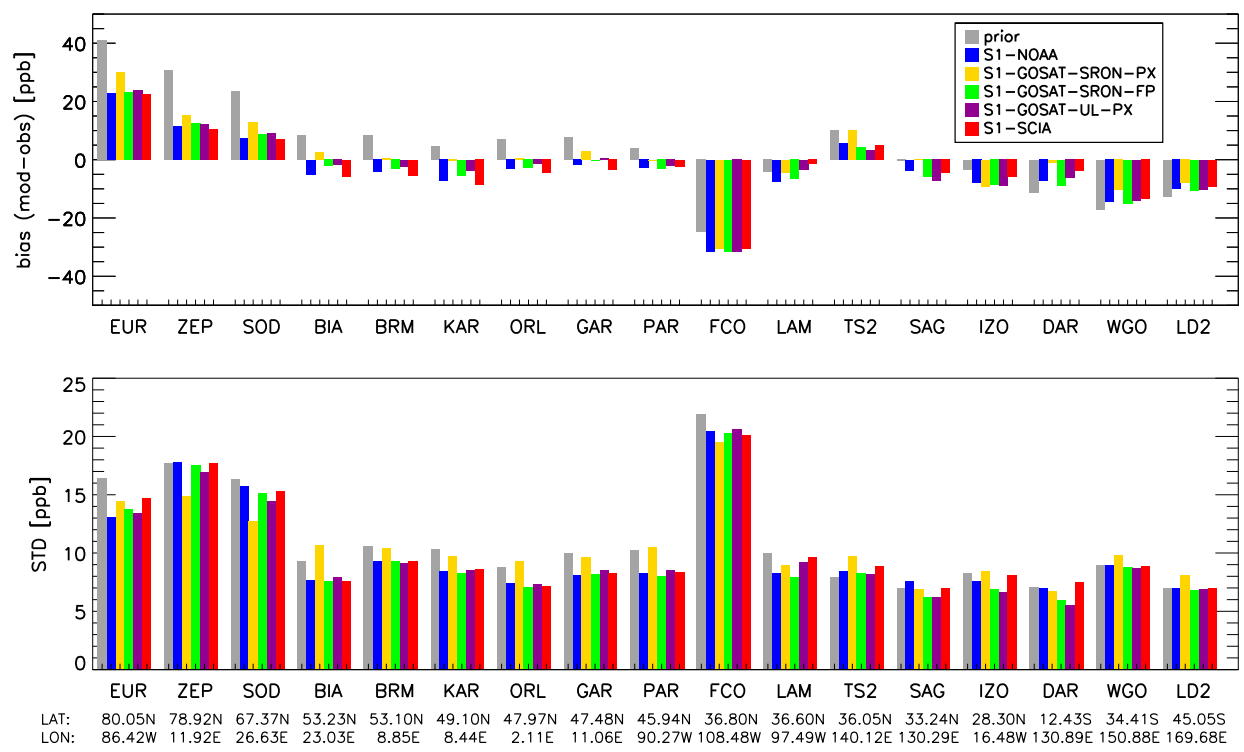

Figure 10. Model validation against TCCON data across all measurement stations with significant data coverage during our inversion period. Prior values are given by the grey bars. Upper panel: bias (in ppb). Lower panel: standard deviation.

Table 5. Two-year average $\mathrm{CH}_{4}$ emissions $\left(\mathrm{TgCH}_{4} \mathrm{yr}^{-1}\right.$ ) for the TRANSCOM land regions (Fig. 5) and $30^{\circ}$ latitude bands. The prior emission inventories are as used by Bergamaschi et al. (2013a). The global total includes the contribution of ocean regions.

\begin{tabular}{lcccccccccc}
\hline & \multirow{2}{*}{ Prior } & S1-NOAA & S1-GOSAT-SRON-PX & \multicolumn{2}{c}{$\mathrm{S}$ S-GOSAT-SRON-FP } & \multicolumn{3}{c}{ S*-GOSAT-UL-PX } & \multicolumn{2}{c}{ S1-SCIA } \\
Region & & & & S1 & S2 & S3 & S1 & S2 & S3 \\
\hline BNA & 13.0 & 11.5 & 11.0 & 12.2 & 13.3 & 12.2 & 10.3 & 11.4 & 10.2 & 10.3 \\
TNA & 38.5 & 47.6 & 44.7 & 44.8 & 41.3 & 43.1 & 52.1 & 47.3 & 51.5 & 45.6 \\
TrSA & 63.7 & 74.9 & 68.9 & 79.4 & 79.6 & 80.7 & 70.7 & 72.4 & 71.6 & 71.8 \\
TSA & 37.5 & 40.9 & 40.9 & 41.7 & 41.5 & 40.5 & 41.3 & 42.3 & 40.7 & 40.2 \\
NAf & 36.7 & 43.0 & 36.1 & 48.0 & 52.7 & 48.1 & 38.3 & 41.7 & 40.2 & 50.6 \\
SAf & 28.5 & 36.4 & 41.6 & 36.4 & 37.7 & 36.2 & 38.4 & 40.0 & 35.7 & 42.0 \\
BEr & 18.1 & 18.1 & 20.6 & 16.8 & 16.7 & 17.0 & 17.0 & 17.4 & 16.7 & 15.4 \\
TEr & 131.4 & 110.1 & 107.5 & 110.4 & 104.7 & 108.9 & 104.0 & 98.1 & 103.0 & 109.6 \\
TrAs & 69.6 & 75.9 & 74.2 & 67.7 & 73.4 & 68.6 & 77.2 & 81.4 & 77.4 & 76.8 \\
Aus & 5.8 & 4.8 & 9.1 & 4.7 & 3.5 & 4.4 & 6.9 & 6.2 & 7.8 & 4.3 \\
Eur & 46.4 & 29.5 & 38.6 & 33.8 & 29.0 & 35.7 & 36.8 & 32.9 & 38.0 & 28.9 \\
\hline Global total & 535.5 & 538.1 & 537.3 & 537.7 & 537.9 & 537.2 & 538.2 & 538.2 & 538.4 & 540.5 \\
\hline Arctic & 19.9 & 17.6 & 21.1 & 18.3 & 19.7 & 18.3 & 17.7 & 20.1 & 17.3 & 18.2 \\
NH-mid & 183.8 & 156.2 & 163.9 & 166.7 & 156.0 & 165.2 & 161.7 & 149.7 & 158.5 & 146.2 \\
NHTr & 193.8 & 202.8 & 182.9 & 192.1 & 196.7 & 193.8 & 197.2 & 199.7 & 207.7 & 215.1 \\
SHTr & 127.7 & 153.9 & 157.4 & 148.1 & 156.5 & 148.5 & 150.6 & 160.1 & 141.6 & 154.8 \\
SH-mid & 14.3 & 11.6 & 15.0 & 16.1 & 12.9 & 14.8 & 13.7 & 11.5 & 16.0 & 8.9 \\
\hline
\end{tabular}

tion and the limitations of the inverse modelling system in differentiating between source categories do not allow us to attribute these emission increments to specific sources.

$\mathrm{CH}_{4}$ fluxes aggregated over the TRANSCOM regions (see Fig. 5 and Gurney et al., 2008) are shown in Fig. 8, and Table 5. All inversions show a small increase in the 2-year global total emissions over the prior, from $1.8 \mathrm{Tg} \mathrm{CH}_{4} \mathrm{yr}^{-1}$ for S1-GOSAT-SRON-PX to $5 \mathrm{Tg} \mathrm{CH}_{4} \mathrm{yr}^{-1}$ for the SCIAMACHY-based S1-SCIA. Emissions in the mid latitudes of the Northern Hemisphere are reduced in all scenarios (mainly across Europe and Temperate Eurasia, see Fig. 8) although there are considerable differences between the flux adjustments calculated for each inversion. The negative increments in the Northern Hemisphere are compensated by across-the-board increases in tropical emissions (between $30^{\circ} \mathrm{N}$ and $30^{\circ} \mathrm{S}$ ) over the prior, between 18.6 $\mathrm{Tg} \mathrm{CH}_{4} \mathrm{yr}^{-1}$ 

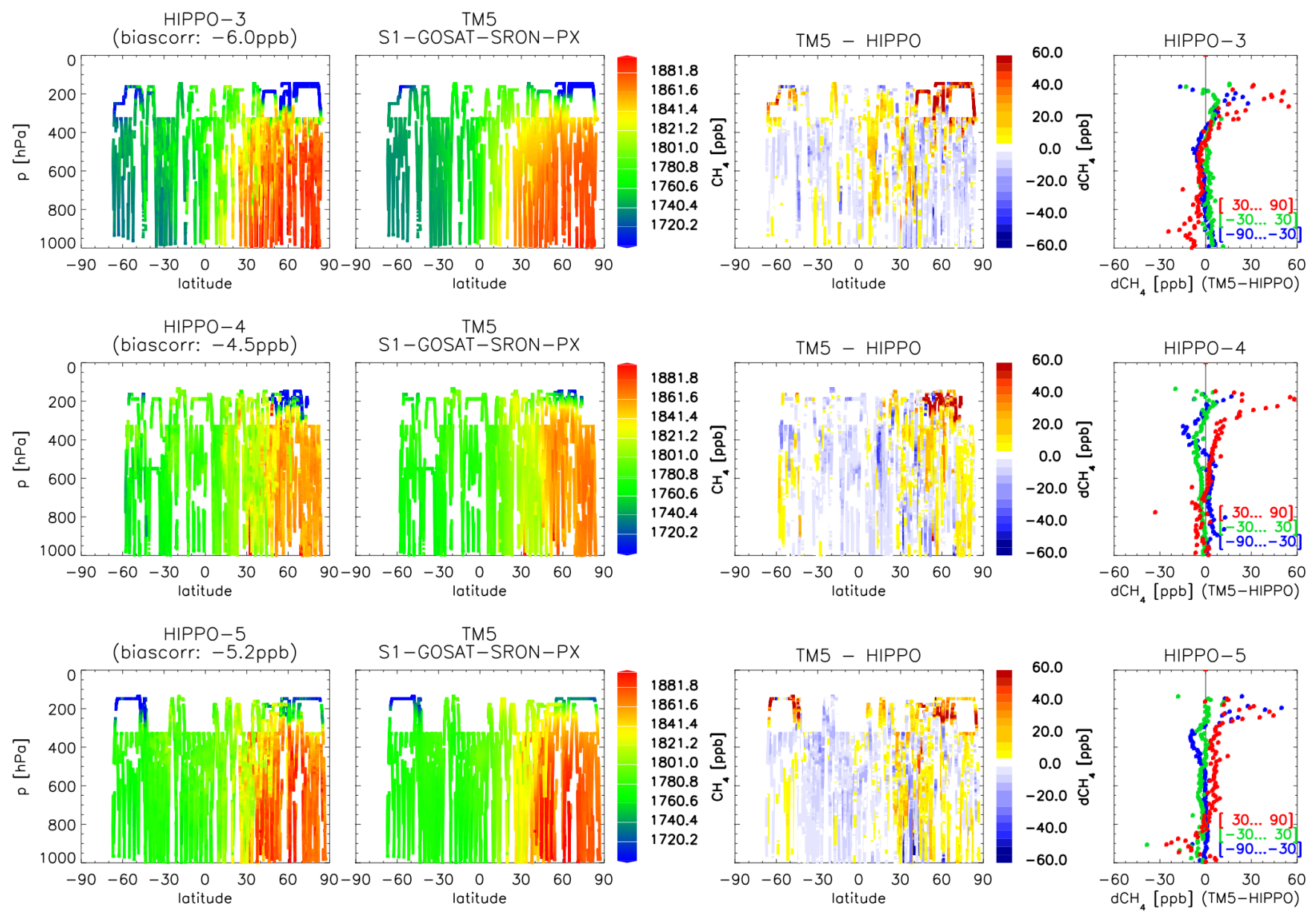

Figure 11. Scenario S1-GOSAT-SRON-PX: validation against HIPPO campaigns 3-5 (southbound and northbound flights). Right panels show the average bias as a function of latitude: extra-tropical Northern Hemisphere in red, extra-tropical Southern Hemisphere in blue, and the tropics in green. HIPPO validation results for the other inversions are shown in the Supplement.

for S1-GOSAT-SRON-FP, and $48.4 \mathrm{Tg} \mathrm{CH}_{4} \mathrm{yr}^{-1}$ for S1SCIA. The net increase in the Southern Hemisphere fluxes can be mainly attributed to increased emissions over Brazil and sub-equatorial Africa. Part of the net increase in the Southern Hemisphere could be due to a bias in the interhemispheric mixing of TM5, as recently diagnosed by $\mathrm{SF}_{6}$ simulations (Patra et al., 2011; Monteil et al., 2013). To tackle this problem, a new parameterization of convective fluxes has been implemented for TM5, based on ERAInterim convective fluxes (Berrisford et al., 2011), instead of the scheme of Tiedtke (1989) used in this study. While it increases inter-hemispheric transport, the new parameterization has a significant impact on the simulated mixing ratios in the continental boundary layer (results not shown). Further investigations are needed to fully evaluate the impact and quality of the new convection scheme (which is beyond the scope of the present study).

Monteil et al. (2013) have reported that inversions using the GOSAT SRON proxy retrievals led to larger Asian emissions than those estimated using the SRON FP $\mathrm{XCH}_{4}$ data set. We noticed a similar pattern in our inversions, particularly above tropical Asia, where S1-GOSAT-SRON-FP flux estimates are ca. $6.5 \mathrm{TgCH}_{4} \mathrm{yr}^{-1}$ lower than those of the GOSAT SRON proxy scenario S1-GOSAT-SRON-PX. Schepers et al. (2012) attribute this discrepancy in the emission estimates to a regional overestimation of $\mathrm{CH}_{4}$ mixing ratios in the proxy retrieval algorithm, caused by deficiencies in the applied $\mathrm{CO}_{2}$ fields. The two GOSAT proxy retrievals yield relatively similar emission patterns overall. There are, however, some differences in the exact magnitude of the regional-scale fluxes calculated by S1-GOSAT-SRONPX and S1-GOSAT-UL-PX, e.g. a larger decrease in temperate Eurasian fluxes when the GOSAT OCPR retrievals are assimilated (see Fig. 6).

Several recent studies (Butz et al., 2011; Schepers et al., 2012) indicated that the reported precision of $\mathrm{XCH}_{4}$ satellite retrievals may be too high. To investigate the impact of applied satellite uncertainties, we considered one additional scenario, in which the reported errors of the GOSAT-SRONPX retrievals were scaled by a factor of 1.5 . This sensitivity 
experiment did not lead to significant changes in the a posteriori regional emission patterns (results not shown).

\subsection{Model validation}

All the inversion results are thoroughly validated against independent measurement data sets covering the atmospheric boundary layer (BL), the free troposphere (FT), as well as the upper troposphere and lower stratosphere (UTLS). Since the observations considered for validation have not been used in the assimilation, they provide an independent verification of the modelled $\mathrm{XCH}_{4}$. Figure 9 gives an overview of the results for all inversions and validation data sets (for a total of slightly more than 80900 observations). See Sect. 2.4 and Fig. 1 for details on each data set. The rms differences shown in Fig. 9 have been averaged over all available measurements during 2010-2011. In general, the optimized $\mathrm{CH}_{4}$ mixing ratios have lower rms differences than the prior concentrations. It is important to note that the a priori shown in Fig. 9 is already partly optimized, given that inversion blocks 2 and 3 (for 2010, and 2011, respectively) start from optimized initial fields (see the discussion in Sect. 3.2). The validation performance of scenario S1-NOAA is generally no worse than that of the satellite inversions. This is likely due to the fact that validation data are generally located far from the regions where the changes in emissions patterns occur (see Fig. 1 and 6), an exception being continental United States, where the agreement between the modelled mixing ratios and boundary layer NOAA aircraft data improves slightly when assimilating satellite retrievals ("BL" panel in Fig. 9). This result is, however, difficult to interpret given the coarse resolution of the model.

\subsection{1 $\mathrm{TCCON} \mathrm{XCH}_{4}$ data}

TCCON provides retrievals of $\mathrm{CH}_{4}$ concentrations at globally distributed locations using ground-based FTS (Wunch et al., 2010). We compare our modelled $\mathrm{XCH}_{4}$ with GGG2012 TCCON retrievals. Figure 10 shows the bias and rms difference between the TM5 and TCCON $\mathrm{XCH}_{4}$, averaged over the entire inversion period. Only stations with sufficient measurement data coverage for 2010-2011 are shown. The grey bars indicate the a priori bias and rms. There is a noticeable improvement in the bias over the prior at the northernmost TCCON stations in Fig. 10. At other regional stations the improvement is modest, and at some stations, e.g. at Four-Corners (FCO), the $\mathrm{XCH}_{4}$ bias slightly deteriorates after the assimilation. However, a recent high-resolution study by Kort et al. (2014) identified the FCO area as a large $\mathrm{CH}_{4}$ anomaly, likely caused by regional sources such as oil, gas, and coal-bed $\mathrm{CH}_{4}$ mining and processing.

We note a systematic trend in the bias from north to south (except for FCO). The positive bias at high northern latitudes could be partly due to overestimated $\mathrm{CH}_{4}$ mixing ratios in the stratosphere (see the comparison of Bergamaschi et al.
(2009) with balloon measurements, and comparisons with HIPPO data in Sect. 4.4.2 and Fig. 11). However, there is also some uncertainty in the TCCON FTS data, since the stratospheric contribution is not directly calibrated and validated (Wunch et al., 2010; Geibel et al., 2012). In future studies, the AirCore $\mathrm{CH}_{4}$ data from NOAA ESRL (Karion et al., 2010) may also serve as an independent benchmark of both model and $\mathrm{TCCON} \mathrm{XCH}_{4}$ in the stratosphere.

\subsubsection{HIPPO aircraft campaigns}

Figure 11 shows the bias corrected HIPPO data for all three campaigns (left panels), and modelled mixing ratios for scenario S1-GOSAT-SRON-PX. There is a good agreement overall between the model simulations and the HIPPO observations (similar results for scenarios S1-GOSAT-SRONFP through S1-SCIA are reported in the Supplement).

The panels on the right in Fig. 11 show the average bias as a function of altitude and latitude band: extra-tropical Northern Hemisphere (red points), tropics (light green), and extra-tropical Southern Hemisphere regions (blue). Agreement between model simulations and the HIPPO measurements in the free troposphere is generally very good for all inversions. However, the bias increases significantly above $300 \mathrm{hPa}$ for all three HIPPO campaigns, particularly in the extra-tropical regions. A similar bias pattern has been reported by Bergamaschi et al. (2013a, Fig. 10). This abrupt deterioration of model performance in the stratosphere is likely caused by deficiencies of the parameterization of the stratospheric sink at high latitudes, and the inability of the coarseresolution TM5 model to resolve the small-scale dynamics of the stratospheric-tropospheric exchange.

\section{Conclusions}

This study compares several inversions of global $\mathrm{CH}_{4}$ emissions for 2010-2011, using four different satellite $\mathrm{XCH}_{4}$ products: the SCIAMACHY IMAPv5.5 retrievals (Frankenberg et al., 2011), the SRON/KIT GOSAT RemoTeC Proxy v1.9/v2.0 and FP v2.1 (Butz et al., 2011; Schepers et al., 2012) retrievals, and the GOSAT OCPR v4.0 product from UL (Parker et al., 2011). All inversions considered are further constrained by highaccuracy $\mathrm{CH}_{4}$ measurement data from the NOAA ESRL global station network (Dlugokencky et al., 2013). The modelled 3-D $\mathrm{CH}_{4}$ fields have been validated against multiple sets of independent observations that were not assimilated.

The inversion results demonstrate clear improvements in the precision and relative accuracy of the GOSAT $\mathrm{XCH}_{4}$ retrievals over SCIAMACHY. The standard deviations of the model-to-observation fit residuals of the GOSAT-based inversions (9-10 ppb) are significantly lower than the value calculated for the SCIAMACHY scenario $(\sim 32 \mathrm{ppb})$. Furthermore, the monthly bias corrections applied to the GOSAT 
retrievals (Fig. 4) are only a fraction of those estimated for the SCIAMACHY retrievals. All the satellite inversions yield qualitatively consistent regional emission patterns, particularly over tropical Africa and United States. The inversions show areas of increased $\mathrm{CH}_{4}$ emissions relative to inventories over South-Central United States, a result consistent with the estimates of Miller et al. (2013), and the recent review of Brandt et al. (2014). The coarse resolution of the model used in this study, and the limitations of the inverse modelling system in differentiating between different source categories do not allow us to attribute these emission increments to specific sources. Nonetheless, the results warrant a more in-depth analysis of $\mathrm{CH}_{4}$ emissions over the North American continent.

It is very encouraging that the GOSAT proxy and GOSAT FP retrievals (which are fundamentally different products of satellite data processing) yield qualitatively very similar spatial emission patterns in the inversions. However, there remain some quantitative differences between the emission increments retrieved by each scenario (particularly over Europe, India, and South America), and the derived 2-year average regional fluxes for the TRANSCOM regions differ by up to $15 \mathrm{Tg} \mathrm{CH}_{4} \mathrm{yr}^{-1}$. For the GOSAT UL Proxy and SRON FP scenarios, the retrieved regional emission estimates show little sensitivity to the particular choice of optimized bias correction scheme (Table 5).

The satellite inversions show similar validation performance. The posterior $\mathrm{CH}_{4}$ mixing ratios have, in general, a lower rms difference to the observations than the prior concentrations. However, validation against the HIPPO profiles demonstrates that a significant bias remains present in the UTLS at higher latitudes, indicating possible deficiencies of the parameterization of the stratospheric sink, or potentially, also transport within the stratosphere. Furthermore, increased horizontal and vertical model resolutions may improve the representation of stratospheric-tropospheric exchange, leading to better agreement with observations in the upper atmosphere. The observed deficiencies of TM5 in the UTLS and stratosphere at high latitudes may partly explain the noticeable north-south trend in the bias between TM5 and TCCON XCH 4 (Fig. 10).

An important diagnostic of the observational constraints are the a posteriori uncertainties. Our choice of nonGaussian prior statistics for the $\mathrm{CH}_{4}$ fluxes precludes the use of the Lanczos algorithm for uncertainty quantification (Meirink et al., 2008b). Alternative approaches are currently being investigated, including the ensemble method described by Chevallier et al. (2007).

The Supplement related to this article is available online at doi:10.5194/acp-15-113-2015-supplement.
Acknowledgements. The authors thank the TCCON principle investigators for making their measurement data available. The TCCON XCH 4 data (GGG2012) were obtained from the TCCON Data Archive, operated by the California Institute of Technology, and hosted at the website http://tccon.ipac.caltech.edu/. US funding for TCCON comes from NASA's Carbon Cycle Program, grant number NNX11AG01G, the Orbiting Carbon Observatory Program, and the DOE/ARM Program. The European TCCON groups involved in this study acknowledge financial support by the EU infrastructure project InGOS. The University of Bremen acknowledges financial support of the Bialystok and Orleans TCCON sites from the Senate of Bremen and EU projects IMECC, GEOmon and InGOS, as well as maintenance and logistical work provided by AeroMeteo Service (Bialystok) and the RAMCES team at LSCE (Gif-sur-Yvette, France), and additional operational funding from the National Institute for Environmental Studies (NIES), Japan. The authors acknowledge Nicholas Deutscher for his kind assistance with the TCCON data processing. CarbonTracker CT2013 results were provided by NOAA ESRL, Boulder, Colorado, USA from the website at http://carbontracker.noaa.gov. This work has been supported by the European Commission Seventh Framework Programme (FP7/2007-2013) projects MACC under grant agreement 218793 and MACC-II under grant agreement 283576. The ECMWF meteorological data has been preprocessed by Philippe Le Sager into the TM5 input format. We thank Greet JanssensMaenhout for providing the EDGARv4.2 emission inventory, and Christoph Brühl for providing the stratospheric $\mathrm{CH}_{4}$ sinks from the ECHAM5/MESSy1 model. ECMWF has kindly provided the necessary computing resources, under the special project "Global and Regional Inverse Modelling of Atmospheric $\mathrm{CH}_{4}$ and $\mathrm{N}_{2} \mathrm{O}$ " (2012-2014). H. Boesch and R. Parker acknowledge funding by the NERC National Centre for Earth Observation and the ESA Climate Change Initiative. André Butz acknowledges support by the Emmy-Noether programme of the Deutsche Forschungsgemeinschaft (DFG) through grant number BU2599/1-1 (RemoteC). Finally, we thank Peter Rayner and the anonymous reviewers for their insightful comments on the manuscript.

Edited by: R. Engelen

\section{References}

Bergamaschi, P., Frankenberg, C., Meirink, J. F., Krol, M., Dentener, F., Wagner, T., Platt, U., Kaplan, J. O., Körner, S., Heimann, M., Dlugokencky, E. J., and Goede, A.: Satellite chartography of atmospheric $\mathrm{CH}_{4}$ from SCIAMACHY on board ENVISAT: 2. Evaluation based on inverse model simulations, J. Geophys. Res.-Atmos., 112, D02304, doi:10.1029/2006JD007268, 2007.

Bergamaschi, P., Frankenberg, C., Meirink, J. F., Krol, M., Villani, M. G., Houweling, S., Dentener, F., Dlugokencky, E. J., Miller, J. B., Gatti, L. V., Engel, A., and Levin, I.: Inverse modeling of global and regional $\mathrm{CH}_{4}$ emissions using SCIAMACHY satellite retrievals, J. Geophys. Res.-Atmos., 114, D22301, doi:10.1029/2009JD012287, 2009.

Bergamaschi, P., Krol, M., Meirink, J. F., Dentener, F., Segers, A., van Aardenne, J., Monni, S., Vermeulen, A. T., Schmidt, M., Ramonet, M., Yver, C., Meinhardt, F., Nisbet, E. G., Fisher, R. E., 
O'Doherty, S., and Dlugokencky, E. J.: Inverse modeling of European $\mathrm{CH}_{4}$ emissions 2001 - 2006, J. Geophys. Res.-Atmos., 115, D22309, doi:10.1029/2010JD014180, 2010.

Bergamaschi, P., Houweling, S., Segers, A., Krol, M., Frankenberg, C., Scheepmaker, R. A., Dlugokencky, E., Wofsy, S. C., Kort, E. A., Sweeney, C., Schuck, T., Brenninkmeijer, C., Chen, H., Beck, V., and Gerbig, C.: Atmospheric $\mathrm{CH}_{4}$ in the first decade of the 21st century: Inverse modeling analysis using SCIAMACHY satellite retrievals and NOAA surface measurements, J. Geophys. Res.-Atmos., 118, 7350-7369, doi:10.1002/jgrd.50480, 2013a.

Bergamaschi, P., Segers, A., Scheepmaker, R., Frankenberg, C., Hasekamp, O., Dlugokencky, E., Sweeney, C., Ramonet, M., Tarniewicz, J., Kort, E., and Wofsy, S.: Report on the quality of the inverted $\mathrm{CH}_{4}$ fluxes, MACC-II Deliverable D_43.3, Tech. rep., Joint Research Center, European Commission, 2013b.

Berrisford, P., Dee, D., Poli, P., Brugge, R., Fielding, K., Fuentes, M., Kallberg, P., Kobayashi, S., Uppala, S., and Simmons, A.: The ERA-Interim archive, Version 2.0, Tech. rep., ECMWF ERA report series, 2011.

Bousquet, P., Ciais, P., Miller, J. B., Dlugokencky, E. J., Hauglustaine, D. A., Prigent, C., Van der Werf, G. R., Peylin, P., Brunke, E.-G., Carouge, C., Langenfelds, R. L., Lathiere, J., Papa, F., Ramonet, M., Schmidt, M., Steele, L. P., Tyler, S. C., and White, J.: Contribution of anthropogenic and natural sources to atmospheric methane variability, Nature, 443, 439443, doi:10.1038/nature05132, 2006.

Brandt, A. R., Heath, G. A., Kort, E. A., O’Sullivan, F., Petron, G., Jordaan, S. M., Tans, P., Wilcox, J., Gopstein, A. M., Arent, D., Wofsy, S., Brown, N. J., Bradley, R., Stucky, G. D., Eardley, D., and Harriss, R.: Methane Leaks from North American Natural Gas Systems, Science, 343, 733-735, doi:10.1126/science.1247045, 2014.

Buchwitz, M., de Beek, R., Burrows, J. P., Bovensmann, H., Warneke, T., Notholt, J., Meirink, J. F., Goede, A. P. H., Bergamaschi, P., Körner, S., Heimann, M., and Schulz, A.: Atmospheric methane and carbon dioxide from SCIAMACHY satellite data: initial comparison with chemistry and transport models, Atmos. Chem. Phys., 5, 941-962, doi:10.5194/acp-5-941-2005, 2005.

Buchwitz, M., Reuter, M., Schneising, O., Boesch, H., Guerlet, S., Dils, B., Aben, I., Armante, R., Bergamaschi, P., Blumenstock, T., Bovensmann, H., Brunner, D., Buchmann, B., Burrows, J., Butz, A., Chédin, A., Chevallier, F., Crevoisier, C., Deutscher, N., Frankenberg, C., Hase, F., Hasekamp, O., Heymann, J., Kaminski, T., Laeng, A., Lichtenberg, G., Mazière, M. D., Noël, S., Notholt, J., Orphal, J., Popp, C., Parker, R., Scholze, M., Sussmann, R., Stiller, G., Warneke, T., Zehner, C., Bril, A., Crisp, D., Griffith, D., Kuze, A., O’Dell, C., Oshchepkov, S., Sherlock, V., Suto, H., Wennberg, P., Wunch, D., Yokota, T., and Yoshida, Y.: The Greenhouse Gas Climate Change Initiative (GHG-CCI): Comparison and quality assessment of near-surface-sensitive satellite-derived $\mathrm{CO}_{2}$ and $\mathrm{CH}_{4}$ global data sets, Remote Sensing of Environment, in press, doi:10.1016/j.rse.2013.04.024, 2013.

Butz, A., Guerlet, S., Hasekamp, O., Schepers, D., Galli, A., Aben, I., Frankenberg, C., Hartmann, J.-M., Tran, H., Kuze, A., Keppel-Aleks, G., Toon, G., Wunch, D., Wennberg, P., Deutscher, N., Griffith, D., Macatangay, R., Messerschmidt, J., Notholt, J., and Warneke, T.: Toward accurate $\mathrm{CO}_{2}$ and $\mathrm{CH}_{4}$ observations from GOSAT, Geophys. Res. Lett., 38, L14812, doi:10.1029/2011GL047888, 2011.
Chevallier, F., Bréon, F.-M., and Rayner, P. J.: Contribution of the Orbiting Carbon Observatory to the estimation of $\mathrm{CO} 2$ sources and sinks: Theoretical study in a variational data assimilation framework, J. Geophys. Res.-Atmos., 112, D09307, doi:10.1029/2006JD007375, 2007.

Chevallier, F., Ciais, P., Conway, T. J., Aalto, T., Anderson, B. E., Bousquet, P., Brunke, E. G., Ciattaglia, L., Esaki, Y., Fröhlich, M., Gomez, A., Gomez-Pelaez, A. J., Haszpra, L., Krummel, P. B., Langenfelds, R. L., Leuenberger, M., Machida, T., Maignan, F., Matsueda, H., Morguí, J. A., Mukai, H., Nakazawa, T., Peylin, P., Ramonet, M., Rivier, L., Sawa, Y., Schmidt, M., Steele, L. P., Vay, S. A., Vermeulen, A. T., Wofsy, S., and Worthy, D.: $\mathrm{CO}_{2}$ surface fluxes at grid point scale estimated from a global 21 year reanalysis of atmospheric measurements, J. Geophys. Res.-Atmos., 115, D21307, doi:10.1029/2010JD013887, 2010.

Cressot, C., Chevallier, F., Bousquet, P., Crevoisier, C., Dlugokencky, E. J., Fortems-Cheiney, A., Frankenberg, C., Parker, R., Pison, I., Scheepmaker, R. A., Montzka, S. A., Krummel, P. B., Steele, L. P., and Langenfelds, R. L.: On the consistency between global and regional methane emissions inferred from SCIAMACHY, TANSO-FTS, IASI and surface measurements, Atmos. Chem. Phys., 14, 577-592, doi:10.5194/acp-14-577-2014, 2014.

Dee, D. P., Uppala, S. M., Simmons, A. J., Berrisford, P., Poli, P., Kobayashi, S., Andrae, U., Balmaseda, M. A., Balsamo, G., Bauer, P., Bechtold, P., Beljaars, A. C. M., van de Berg, L., Bidlot, J., Bormann, N., Delsol, C., Dragani, R., Fuentes, M., Geer, A. J., Haimberger, L., Healy, S. B., Hersbach, H., Holm, E. V., Isaksen, L., Kållberg, P., Köhler, M., Matricardi, M., McNally, A. P., Monge-Sanz, B. M., Morcrette, J.-J., Park, B.-K., Peubey, C., de Rosnay, P., Tavolato, C., Thépaut, J.-N., and Vitart, F.: The ERA-Interim reanalysis: configuration and performance of the data assimilation system, Q. J. Roy. Meteor. Soc., 137, 553-597, doi:10.1002/qj.828, 2011.

Dlugokencky, E., Lang, P. M., Crotwell, A. M., Masarie, K. A., and Crotwell, M. J.: Atmospheric methane dry-air mole fractions from the NOAA ESRL carbon cycle cooperative global air sampling network: 1988-2012, version: 2013-06-18, ftp://ftp.cmdl. noaa.gov/ccg/ch4/flask/surface (last access: 18 November 2013), 2013.

Dlugokencky, E. J., Steele, L. P., Lang, P. M., and Masarie, K. A.: The growth rate and distribution of atmospheric methane, J. Geophys. Res.-Atmos., 99, 17021-17043, doi:10.1029/94JD01245, 1994.

Dlugokencky, E. J., Houweling, S., Bruhwiler, L., Masarie, K. A., Lang, P. M., Miller, J. B., and Tans, P. P.: Atmospheric methane levels off: Temporary pause or a new steady-state?, Geophys. Res. Lett., 30, 1992, doi:10.1029/2003GL018126, 2003.

Dlugokencky, E. J., Myers, R. C., Lang, P. M., Masarie, K. A., Crotwell, A. M., Thoning, K. W., Hall, B. D., Elkins, J. W., and Steele, L. P.: Conversion of NOAA atmospheric dry-air $\mathrm{CH}_{4}$ mole fractions to a gravimetrically prepared standard scale, J. Geophys. Res.-Atmos., 110, D18306, doi:10.1029/2005JD006035, 2005.

Dlugokencky, E. J., Bruhwiler, L., White, J. W. C., Emmons, L. K., Novelli, P. C., Montzka, S. A., Masarie, K. A., Lang, P. M., Crotwell, A. M., Miller, J. B., and Gatti, L. V.: Observational constraints on recent increases in the atmospheric $\mathrm{CH}_{4}$ burden, Geophys. Res. Lett., 36, L18803, doi:10.1029/2009GL039780, 2009. 
Frankenberg, C., Meirink, J. F., van Weele, M., Platt, U., and Wagner, T.: Assessing Methane Emissions from Global Space-Borne Observations, Science, 308, 1010-1014, doi:10.1126/science.1106644, 2005.

Frankenberg, C., Meirink, J. F., Bergamaschi, P., Goede, A. P. H., Heimann, M., Körner, S., Platt, U., van Weele, M., and Wagner, T.: Satellite chartography of atmospheric methane from SCIAMACHY on board ENVISAT: Analysis of the years 2003 and 2004, J. Geophys. Res.-Atmos., 111, D07303, doi:10.1029/2005JD006235, 2006.

Frankenberg, C., Bergamaschi, P., Butz, A., Houweling, S., Meirink, J. F., Notholt, J., Petersen, A. K., Schrijver, H., Warneke, T., and Aben, I.: Tropical methane emissions: A revised view from SCIAMACHY onboard ENVISAT, Geophys. Res. Lett., 35, L15811, doi:10.1029/2008GL034300, 2008.

Frankenberg, C., Aben, I., Bergamaschi, P., Dlugokencky, E. J., van Hees, R., Houweling, S., van der Meer, P., Snel, R., and Tol, P.: Global column-averaged methane mixing ratios from 2003 to 2009 as derived from SCIAMACHY: Trends and variability, J. Geophys. Res.-Atmos., 116, D04302, doi:10.1029/2010JD014849, 2011.

Fraser, A., Palmer, P. I., Feng, L., Boesch, H., Cogan, A., Parker, R., Dlugokencky, E. J., Fraser, P. J., Krummel, P. B., Langenfelds, R. L., O’Doherty, S., Prinn, R. G., Steele, L. P., van der Schoot, M., and Weiss, R. F.: Estimating regional methane surface fluxes: the relative importance of surface and GOSAT mole fraction measurements, Atmos. Chem. Phys., 13, 5697-5713, doi:10.5194/acp-13-5697-2013, 2013.

Geibel, M. C., Messerschmidt, J., Gerbig, C., Blumenstock, T., Chen, H., Hase, F., Kolle, O., Lavrič, J. V., Notholt, J., Palm, M., Rettinger, M., Schmidt, M., Sussmann, R., Warneke, T., and Feist, D. G.: Calibration of column-averaged $\mathrm{CH}_{4}$ over European TCCON FTS sites with airborne in-situ measurements, Atmos. Chem. Phys., 12, 8763-8775, doi:10.5194/acp-12-87632012, 2012.

Gilbert, J. C. and Lemaréchal, C.: Some Numerical Experiments with Variable-storage quasi-Newton Algorithms, Math. Program., 45, 407-435, doi:10.1007/BF01589113, 1989.

Gurney, K. R., Baker, D., Rayner, P., and Denning, S.: Interannual variations in continental-scale net carbon exchange and sensitivity to observing networks estimated from atmospheric $\mathrm{CO}_{2}$ inversions for the period 1980 to 2005, Global Biogeochem. Cy., 22, GB3025, doi:10.1029/2007GB003082, 2008.

Hein, R., Crutzen, P. J., and Heimann, M.: An inverse modeling approach to investigate the global atmospheric methane cycle, Global Biogeochem. Cy., 11, 43-76, doi:10.1029/96GB03043, 1997.

Houweling, S., Kaminski, T., Dentener, F., Lelieveld, J., and Heimann, M.: Inverse modeling of methane sources and sinks using the adjoint of a global transport model, J. Geophys. Res.Atmos., 104, 26137-26160, doi:10.1029/1999JD900428, 1999.

Houweling, S., Krol, M., Bergamaschi, P., Frankenberg, C., Dlugokencky, E. J., Morino, I., Notholt, J., Sherlock, V., Wunch, D., Beck, V., Gerbig, C., Chen, H., Kort, E. A., Röckmann, T., and Aben, I.: A multi-year methane inversion using SCIAMACHY, accounting for systematic errors using TCCON measurements, Atmos. Chem. Phys., 14, 3991-4012, doi:10.5194/acp-14-39912014, 2014.
Jöckel, P., Tost, H., Pozzer, A., Brühl, C., Buchholz, J., Ganzeveld, L., Hoor, P., Kerkweg, A., Lawrence, M., Sander, R., Steil, B., Stiller, G., Tanarhte, M., Taraborrelli, D., van Aardenne, J., and Lelieveld, J.: The atmospheric chemistry general circulation model ECHAM5/MESSy1: consistent simulation of ozone from the surface to the mesosphere, Atmos. Chem. Phys., 6, 50675104, doi:10.5194/acp-6-5067-2006, 2006.

Karion, A., Sweeney, C., Tans, P., and Newberger, T.: AirCore: An Innovative Atmospheric Sampling System, J. Atmos. Ocean. Technol., 27, 1839-1853, doi:10.1175/2010JTECHA1448.1, 2010.

Kirschke, S., Bousquet, P., Ciais, P., Saunois, M., Canadell, J. G., Dlugokencky, E. J., Bergamaschi, P., Bergmann, D., Blake, D. R., Bruhwiler, L., Cameron-Smith, P., Castaldi, S., Chevallier, F., Feng, L., Fraser, A., Heimann, M., Hodson, E. L., Houweling, S., Josse, B., Fraser, P. J., Krummel, P. B., Lamarque, J. F., Langenfelds, R. L., Le Quere, C., Naik, V., O’Doherty, S., Palmer, P. I., Pison, I., Plummer, D., Poulter, B., Prinn, R. G., Rigby, M., Ringeval, B., Santini, M., Schmidt, M., Shindell, D. T., Simpson, I., Spahni, R., Steele, L. P., Strode, S. A., Sudo, K., Szopa, S., van der Werf, G. R., Voulgarakis, A., van Weele, M., Weiss, R. F., Williams, J. E., and Zeng, G.: Three decades of global methane sources and sinks, Nature Geosci., 6, 813-823, doi:10.1038/ngeo1955, 2013.

Kort, E. A., Eluszkiewicz, J., Stephens, B. B., Miller, J. B., Gerbig, C., Nehrkorn, T., Daube, B. C., Kaplan, J. O., Houweling, S., and Wofsy, S. C.: Emissions of $\mathrm{CH}_{4}$ and $\mathrm{N}_{2} \mathrm{O}$ over the United States and Canada based on a receptor-oriented modeling framework and COBRA-NA atmospheric observations, Geophys. Res. Lett., 35, L18808, doi:10.1029/2008GL034031, 2008.

Kort, E. A., Wofsy, S. C., Daube, B. C., Diao, M., Elkins, J. W., Gao, R. S., Hintsa, E. J., Hurst, D. F., Jimenez, R., and Moore, F. L.: Atmospheric observations of Arctic Ocean methane emissions up to $82^{\circ}$ north, Nature Geosci., 318-321, doi:10.1038/ngeo1452, 2012.

Kort, E. A., Frankenberg, C., Costigan, K. R., Lindenmaier, R., Dubey, M. K., and Wunch, D.: Four corners: The largest US methane anomaly viewed from space, Geophys. Res. Lett., 41, 6898-6903, doi:10.1002/2014GL061503, 2014.

Krol, M., Houweling, S., Bregman, B., van den Broek, M., Segers, A., van Velthoven, P., Peters, W., Dentener, F., and Bergamaschi, P.: The two-way nested global chemistry-transport zoom model TM5: algorithm and applications, Atmos. Chem. Phys., 5, 417432, doi:10.5194/acp-5-417-2005, 2005.

Krol, M. C., Meirink, J. F., Bergamaschi, P., Mak, J. E., Lowe, D., Jöckel, P., Houweling, S., and Röckmann, T.: What can ${ }^{14} \mathrm{CO}$ measurements tell us about $\mathrm{OH}$ ?, Atmos. Chem. Phys., 8, 50335044, doi:10.5194/acp-8-5033-2008, 2008.

Meirink, J. F., Bergamaschi, P., Frankenberg, C., d'Amelio, M. T. S., Dlugokencky, E. J., Gatti, L. V., Houweling, S., Miller, J. B., Röckmann, T., Villani, M. G., and Krol, M. C.: Four-dimensional variational data assimilation for inverse modeling of atmospheric methane emissions: Analysis of SCIAMACHY observations, J. Geophys. Res.-Atmos., 113, D17301, doi:10.1029/2007JD009740, 2008a.

Meirink, J. F., Bergamaschi, P., and Krol, M. C.: Fourdimensional variational data assimilation for inverse modelling of atmospheric methane emissions: method and comparison 
with synthesis inversion, Atmos. Chem. Phys., 8, 6341-6353, doi:10.5194/acp-8-6341-2008, 2008b.

Melton, J. R., Wania, R., Hodson, E. L., Poulter, B., Ringeval, B., Spahni, R., Bohn, T., Avis, C. A., Beerling, D. J., Chen, G., Eliseev, A. V., Denisov, S. N., Hopcroft, P. O., Lettenmaier, D. P., Riley, W. J., Singarayer, J. S., Subin, Z. M., Tian, H., Zürcher, S., Brovkin, V., van Bodegom, P. M., Kleinen, T., Yu, Z. C., and Kaplan, J. O.: Present state of global wetland extent and wetland methane modelling: conclusions from a model intercomparison project (WETCHIMP), Biogeosciences, 10, 753788, doi:10.5194/bg-10-753-2013, 2013.

Mikaloff Fletcher, S. E., Tans, P. P., Bruhwiler, L. M., Miller, J. B., and Heimann, M.: $\mathrm{CH}_{4}$ sources estimated from atmospheric observations of $\mathrm{CH}_{4}$ and its $13 \mathrm{C} / 12 \mathrm{C}$ isotopic ratios: 1 . Inverse modeling of source processes, Global Biogeochem. Cy., 18, GB4004, doi:10.1029/2004GB002223, 2004a.

Mikaloff Fletcher, S. E., Tans, P. P., Bruhwiler, L. M., Miller, J. B., and Heimann, M.: $\mathrm{CH}_{4}$ sources estimated from atmospheric observations of $\mathrm{CH}_{4}$ and its $13 \mathrm{C} / 12 \mathrm{C}$ isotopic ratios: 2 . Inverse modeling of $\mathrm{CH}_{4}$ fluxes from geographical regions, Global Biogeochem. Cy., 18, GB4005, doi:10.1029/2004GB002224, 2004 b.

Miller, S. M., Wofsy, S. C., Michalak, A. M., Kort, E. A., Andrews, A. E., Biraud, S. C., Dlugokencky, E. J., Eluszkiewicz, J., Fischer, M. L., Janssens-Maenhout, G., Miller, B. R., Miller, J. B., Montzka, S. A., Nehrkorn, T., and Sweeney, C.: Anthropogenic emissions of methane in the United States, P. Natl. Acad. Sci., 110, 20018-20022, doi:10.1073/pnas.1314392110, 2013.

Monteil, G., Houweling, S., Butz, A., Guerlet, S., Schepers, D., Hasekamp, O., Frankenberg, C., Scheepmaker, R., Aben, I., and Röckmann, T.: Comparison of $\mathrm{CH}_{4}$ inversions based on 15 months of GOSAT and SCIAMACHY observations, J. Geophys. Res.-Atmos., 118, 11807-11823, doi:10.1002/2013JD019760, 2013.

Nisbet, E. G., Dlugokencky, E. J., and Bousquet, P.: Methane on the Rise-Again, Science, 343, 493-495, doi:10.1126/science.1247828, 2014.

Parker, R., Boesch, H., Cogan, A., Fraser, A., Feng, L., Palmer, P. I., Messerschmidt, J., Deutscher, N., Griffith, D. W. T., Notholt, J., Wennberg, P. O., and Wunch, D.: Methane observations from the Greenhouse Gases Observing SATellite: Comparison to groundbased TCCON data and model calculations, Geophys. Res. Lett., 38, L15807, doi:10.1029/2011GL047871, 2011.

Parrish, D. F. and Derber, J. C.: The National Meteorological Center's Spectral Statistical-Interpolation Analysis System, Mon. Weather Rev., 120, 1747-1763, doi:10.1175/15200493(1992)120, 1992.

Patra, P. K., Houweling, S., Krol, M., Bousquet, P., Belikov, D., Bergmann, D., Bian, H., Cameron-Smith, P., Chipperfield, M. P., Corbin, K., Fortems-Cheiney, A., Fraser, A., Gloor, E., Hess, P., Ito, A., Kawa, S. R., Law, R. M., Loh, Z., Maksyutov, S., Meng, L., Palmer, P. I., Prinn, R. G., Rigby, M., Saito, R., and Wilson, C.: TransCom model simulations of $\mathrm{CH}_{4}$ and related species: linking transport, surface flux and chemical loss with $\mathrm{CH}_{4}$ variability in the troposphere and lower stratosphere, Atmos. Chem. Phys., 11, 12813-12837, doi:10.5194/acp-11-12813-2011, 2011.

Peters, W., Jacobson, A. R., Sweeney, C., Andrews, A. E., Conway, T. J., Masarie, K., Miller, J. B., Bruhwiler, L. M. P., Pétron, G., Hirsch, A. I., Worthy, D. E. J., van der Werf, G. R., Randerson, J. T., Wennberg, P. O., Krol, M. C., and Tans, P. P.: An atmospheric perspective on North American carbon dioxide exchange: CarbonTracker, P. Natl. Acad. Sci., 104, 18925-18930, doi:10.1073/pnas.0708986104, 2007.

Rigby, M., Prinn, R. G., Fraser, P. J., Simmonds, P. G., Langenfelds, R. L., Huang, J., Cunnold, D. M., Steele, L. P., Krummel, P. B., Weiss, R. F., O'Doherty, S., Salameh, P. K., Wang, H. J., Harth, C. M., Mühle, J., and Porter, L. W.: Renewed growth of atmospheric methane, Geophys. Res. Lett., 35, L22805, doi:10.1029/2008GL036037, 2008.

Rodgers, C. D. and Connor, B. J.: Intercomparison of remote sounding instruments, J. Geophys. Res.-Atmos., 108, 4116, doi:10.1029/2002JD002299, 2003.

Schepers, D., Guerlet, S., Butz, A., Landgraf, J., Frankenberg, C., Hasekamp, O., Blavier, J.-F., Deutscher, N. M., Griffith, D. W. T., Hase, F., Kyro, E., Morino, I., Sherlock, V., Sussmann, R., and Aben, I.: Methane retrievals from Greenhouse Gases Observing Satellite (GOSAT) shortwave infrared measurements: Performance comparison of proxy and physics retrieval algorithms, J. Geophys. Res.-Atmos., 117, D10307, doi:10.1029/2012JD017549, 2012.

Schneising, O., Bergamaschi, P., Bovensmann, H., Buchwitz, M., Burrows, J. P., Deutscher, N. M., Griffith, D. W. T., Heymann, J., Macatangay, R., Messerschmidt, J., Notholt, J., Rettinger, M., Reuter, M., Sussmann, R., Velazco, V. A., Warneke, T., Wennberg, P. O., and Wunch, D.: Atmospheric greenhouse gases retrieved from SCIAMACHY: comparison to ground-based FTS measurements and model results, Atmos. Chem. Phys., 12, 1527-1540, doi:10.5194/acp-12-1527-2012, 2012.

Simpson, I., Rowland, F. S., Meinardi, S., and Blake, D. R.: Influence of biomass burning during recent fluctuations in the slow growth of global tropospheric methane, Geophys. Res. Lett., 33, L22808, doi:10.1029/2006GL027330, 2006.

Spivakovsky, C. M., Logan, J. A., Montzka, S. A., Balkanski, Y. J., Foreman-Fowler, M., Jones, D. B. A., Horowitz, L. W., Fusco, A. C., Brenninkmeijer, C. A. M., Prather, M. J., Wofsy, S. C., and McElroy, M. B.: Three-dimensional climatological distribution of tropospheric OH: Update and evaluation, J. Geophys. Res.Atmos., 105, 8931-8980, doi:10.1029/1999JD901006, 2000.

Stocker, T., Qin, D., Plattner, G. K., Tignor, M., Allen, S. K., Boschung, J., Nauels, A., Xia, Y., Bex, V., and Midgley, P. M., eds.: Summary for Policymakers, Climate Change 2013: The Physical Science Basis, Contribution of Working Group I to the Fifth Assessment Report of the Intergovernmental Panel on Climate Change, Cambridge University Press, Cambridge, UK and New York, NY, USA, 1-29, 2013.

Tarantola, A.: Inverse Problem Theory and Methods for Model Parameter Estimation, Society for Industrial and Applied Mathematics, Philadelphia, PA, USA, 1-342, 2004.

Tiedtke, M.: A Comprehensive Mass Flux Scheme for Cumulus Parameterization in Large-Scale Models, Mon. Weather Rev., 117, 1779-1800, 1989.

Velders, G.: Description of the RIVM 2-dimensional stratosphere model, Tech. Rep. 722201002, RIVM report, 1995.

Vermeulen, A. T., Schmidt, M., Manning, A., Moors, E., Moncrieff, J., Haszpra, L., Stefani, P., and Lindroth, A.: CHIOTTO: Final project report, Tech. Rep. ECN-E-07-052, ECN Petten, 2007.

WMO: WMO greenhouse gas bulletin - The State of Greenhouse Gases in the Atmosphere Based on Global Observations through 2012, 1-4, 2013. 
Wofsy, S. C.: HIAPER Pole-to-Pole Observations (HIPPO): finegrained, global-scale measurements of climatically important atmospheric gases and aerosols, Philosophical Transactions of the Royal Society A, 369, 2073-2086, doi:10.1098/rsta.2010.0313, 2011.

Wunch, D., Toon, G. C., Wennberg, P. O., Wofsy, S. C., Stephens, B. B., Fischer, M. L., Uchino, O., Abshire, J. B., Bernath, P., Biraud, S. C., Blavier, J.-F. L., Boone, C., Bowman, K. P., Browell, E. V., Campos, T., Connor, B. J., Daube, B. C., Deutscher, N. M., Diao, M., Elkins, J. W., Gerbig, C., Gottlieb, E., Griffith, D. W. T., Hurst, D. F., Jiménez, R., Keppel-Aleks, G., Kort, E. A., Macatangay, R., Machida, T., Matsueda, H., Moore, F., Morino, I., Park, S., Robinson, J., Roehl, C. M., Sawa, Y., Sherlock, V., Sweeney, C., Tanaka, T., and Zondlo, M. A.: Calibration of the Total Carbon Column Observing Network using aircraft profile data, Atmos. Meas. Tech., 3, 1351-1362, doi:10.5194/amt3-1351-2010, 2010.
Yoshida, Y., Ota, Y., Eguchi, N., Kikuchi, N., Nobuta, K., Tran, H., Morino, I., and Yokota, T.: Retrieval algorithm for $\mathrm{CO}_{2}$ and $\mathrm{CH}_{4}$ column abundances from short-wavelength infrared spectral observations by the Greenhouse gases observing satellite, Atmos. Meas. Tech., 4, 717-734, doi:10.5194/amt-4-717-2011, 2011. 